\title{
Plicosepalus acacia Extract and Its Major Constituents, Methyl Gallate and Quercetin, Potentiate Therapeutic Angiogenesis in Diabetic Hind Limb Ischemia: HPTLC Quantification and LC-MS/MS Metabolic Profiling
}

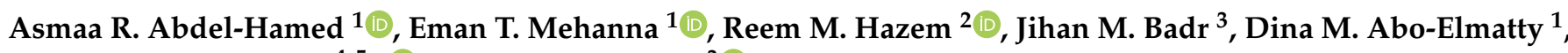 \\ Maged S. Abdel-Kader $4,5, *\left(\mathbb{D}\right.$ and Marwa S. Goda ${ }^{3}(\mathbb{D}$ \\ 1 Department of Biochemistry, Faculty of Pharmacy, Suez Canal University, Ismailia 41522, Egypt; \\ asmaa.ramdan@pharm.suez.edu.eg (A.R.A.-H.); eman.taha@pharm.suez.edu.eg (E.T.M.); \\ dina_abouelmouti@pharm.suez.edu.eg (D.M.A.-E.) \\ 2 Department of Pharmacology and Toxicology, Faculty of Pharmacy, Suez Canal University, \\ Ismailia 41522, Egypt; reem_ahmed@pharm.suez.edu.eg \\ 3 Department of Pharmacognosy, Faculty of Pharmacy, Suez Canal University, Ismailia 41522, Egypt; \\ gehan_ibrahim@pharm.suez.edu.eg (J.M.B.); marwa_saeed@pharm.suez.edu.eg (M.S.G.) \\ 4 Department of Pharmacognosy, College of Pharmacy, Prince Sattam Bin Abdulaziz University 173, \\ Al-Kharj 11942, Saudi Arabia \\ 5 Department of Pharmacognosy, College of Pharmacy, Alexandria University, Alexandria 21215, Egypt \\ * Correspondence: m.youssef@psau.edu.sa; Tel.: +966-545-539-145
}

\section{check for}

updates

Citation: Abdel-Hamed, A.R.; Mehanna, E.T.; Hazem, R.M.; Badr, J.M.; Abo-Elmatty, D.M.;

Abdel-Kader, M.S.; Goda, M.S.

Plicosepalus acacia Extract and Its Major Constituents, Methyl Gallate and Quercetin, Potentiate Therapeutic Angiogenesis in Diabetic Hind Limb Ischemia: HPTLC Quantification and LC-MS/MS Metabolic Profiling. Antioxidants 2021, 10, 1701. https:// doi.org/10.3390/antiox10111701

Received: 30 September 2021

Accepted: 25 October 2021

Published: 27 October 2021

Publisher's Note: MDPI stays neutral with regard to jurisdictional claims in published maps and institutional affiliations.

Copyright: (c) 2021 by the authors. Licensee MDPI, Basel, Switzerland. This article is an open access article distributed under the terms and conditions of the Creative Commons Attribution (CC BY) license (https:// creativecommons.org/licenses/by/ $4.0 /)$.
Abstract: Plicosepalus acacia (Fam. Loranthaceae) has been reported to possess hypoglycemic, antioxidant, antimicrobial, and anti-inflammatory effects. Liquid chromatography combined with tandem mass spectrometry (LC-MS/MS) analysis revealed the presence of a high content of polyphenolic compounds that are attributed to the therapeutic effects of the crude extract. In addition, methyl gallate and quercetin were detected as major phytomedicinal agents at concentrations of $1.7 \%$ and $0.062 \mathrm{~g} \%$, respectively, using high-performance thin layer chromatography (HPTLC). The present study investigated the effect of the P. acacia extract and its isolated compounds, methyl gallate and quercetin, on hind limb ischemia induced in type 1 diabetic rats. Histopathological examination revealed that treatment with $P$. acacia extract, methyl gallate, and quercetin decreased degenerative changes and inflammation in the ischemic muscle. Further biochemical assessment of the hind limb tissue showed decreased oxidative stress, increased levels of nitric oxide and endothelial nitric oxide synthase (eNOS), and enhancement of the levels of heme oxygenase-1 (HO-1) and vascular endothelial growth factor (VEGF) in the groups treated with methyl gallate and quercetin. Expression levels of hypoxia inducible factor-1 alpha (HIF-1 $\alpha$ ), VEGF, fibroblast growth factor-2 (FGF-2), and miR-146a were upregulated in the muscle tissue of methyl gallate- and quercetin-treated groups along with downregulation of nuclear factor kappa B (NF-kB). In conclusion, P. acacia extract and its isolated compounds, methyl gallate and quercetin, mediated therapeutic angiogenesis in diabetic hind limb ischemia.

Keywords: Plicosepalus acacia; LC-MS/MS; methyl gallate; quercetin; HPTLC; hind limb ischemia; therapeutic angiogenesis; VEGF; miR-146a

\section{Introduction}

Diabetes mellitus increases the risk of developing ischemic vascular disease, especially peripheral artery disease (PAD). PAD arises from the occlusion of blood flow in peripheral arteries, leading to ischemia and hypoxia of tissue. Neoangiogenesis, "The sprouting of new blood capillaries from preexisting vessels", takes place in response to ischemia. However, the capability of forming new blood vessels is impaired in diabetic patients with PAD [1]. As 
a result, PAD in these patients may cause limb amputation and mortality [2]. Management of severe PAD is mainly through surgery and endovascular revascularization [3]. However, surgical interventions are not suitable for all diabetic patients [4]. Hence, the search for new therapeutic modalities became necessary.

Therapeutic angiogenesis is an alternate approach for improving blood flow and encouraging blood vessel growth [5]. Angiogenesis is chiefly motivated by ischemia, ischemia-induced transcription factors such as hypoxia inducible factor-1 (HIF-1), and the genes dependent on these factors, such as vascular endothelial growth factor (VEGF) [6]. Therapeutic angiogenesis was applied using cytokines to stimulate angiogenesis or transplanting cells such as endothelial progenitor cells in bone marrow to differentiate into endothelial cells and yield proangiogenic cytokines [7], but angiogenic cytokines may generate pathological vessels and cause some complications [8]. This limits the clinical use of therapeutic angiogenesis, and it is still considered a great challenge. Thus, a new strategy beyond administrating extreme amounts of angiogenic factors is needed.

Many mechanisms are involved in ischemia/reperfusion injury such as oxidative stress and mitochondrial dysfunction [9]. Heme oxygenase-1 (HO-1) is a stress-induced protective enzyme enhancing tissue regeneration. HO-1 was reported to be a mediator of VEGF-induced angiogenesis [10]. Endothelial nitric oxide synthase (eNOS) provokes many useful cardiovascular effects. Besides its vasodilatory properties, eNOS-derived nitric oxide (NO) plays a serious role in angiogenesis following tissue ischemia [11]. NO has a high affinity for heme and it strongly upregulates HO-1 [12].

The family Loranthaceae represents the largest family of the order Santalales with about 70 genera and 800 species of semi-parasitic plants commonly known as mistletoes. They tend to parasitize a broad range of gymnosperms and angiosperms causing serious damage to their hosts [13-15]. Despite their damaging effect on plants, they have been used in ethnomedicine for various purposes, including the treatment of diarrhea, tonsillitis, otitis media, and diabetes [16-18]. Plicosepalus acacia is a plant that belongs to the family Loranthaceae and is abundant in the Saudi kingdom. It is widely used in traditional medicine for the treatment of variable diseases and has been proved to possess anti-inflammatory, antimicrobial, hepatoprotective, and hypoglycemic functions $[19,20]$. A previous investigation of the chemical constituents of the plant revealed the accumulation of a number of phenolic compounds with significant antioxidant effects, of which methyl gallate and quercetin were major components [21]. The quercetin concentration was previously determined to be $0.062 \mathrm{~g} \%$ using high-performance thin layer chromatography (HPTLC) [22]. The current study aimed to continue the previous work through HPTLC quantification of methyl gallate in addition to the identification of natural metabolites in P. acacia using liquid chromatography coupled to tandem mass spectrometry (LC-MS/MS). The current work also investigated the effect of the P. acacia extract and its isolated compounds, methyl gallate and quercetin, on therapeutic angiogenesis in experimentally induced diabetic hind limb ischemia and the possible underlying mechanisms of this effect through the assessment of ischemia-induced, antioxidant, and angiogenic markers.

\section{Materials and Methods}

\subsection{Plant Material and Metabolic Analysis Profiling Using LC/ESI-TOF-MS/MS}

\subsubsection{Plant Collection and Extraction}

The plant was previously collected in March 2010 from Alola in the North of Saudi Arabia and was identified by Dr. Nahed Morad, Faculty of Science, King Abdulaziz University. A voucher sample was preserved and given the registration code No. 2010PA1. The plant was air dried, finely ground followed by maceration with methyl alcohol $(3 \times 4000 \mathrm{~mL})$ at room temperature. The total alcoholic extract was concentrated under vacuum and kept in a refrigerator. 


\subsubsection{Metabolic Analysis Profiling Using LC/ESI-TOF-MS/MS}

High-performance liquid chromatography combined with electrospray time-of-flight tandem mass spectrometry (LC/ESI-TOF-MS/MS) was assessed as described before in detail [23,24]. In brief, $50 \mathrm{mg}$ of the methanolic crude extract of $P$. acacia was dissolved in $1 \mathrm{~mL}$ of a solvent mixture of water: methanol: acetonitrile (50:25:25), ultra-sonicated for $10 \mathrm{~min}$ and then centrifuged for $10 \mathrm{~min}$ at $10,000 \mathrm{rpm}$. An aliquot of $50 \mu \mathrm{L}$ was diluted with $1000 \mu \mathrm{L}$ of the afore-mentioned solvent mixture to obtain a final concentration of $2.5 \mu \mathrm{g} / \mu \mathrm{L}$. An amount of $10 \mu \mathrm{L}$ was injected in both positive and negative modes. The LC-MS analysis was also repeated for blanks for confidence in the experiment. The LC/ESI-TOF-MS/MS analysis was performed on an ExionLC system (AB Sciex, Framingham, MA, USA) using an autosampler system, an in-line filter disks pre-column $(0.5 \mu \mathrm{m} \times 3.0 \mathrm{~mm}$, Phenomenex, Torrance, CA, USA), and an X select HSS T3 column $(2.5 \mu \mathrm{m}, 2.1 \times 150 \mathrm{~mm}$, Waters Corporation, Milford, MA, USA) sustained at $40{ }^{\circ} \mathrm{C}$. The mobile phase consisted of $5 \mathrm{mM}$ ammonium formate buffer in $1 \%$ methanol with $\mathrm{pH}$ adjusted to 3.0 using formic acid for positive mode or adjusted to 8.0 using sodium hydroxide for negative mode. The gradient elution technique was done by increasing the concentration of acetonitrile from $10 \%$ to $90 \%$ within $20 \mathrm{~min}$, followed by an isocratic period of $4 \mathrm{~min}$ and finally reducing the concentration of acetonitrile to $10 \%$ within $3 \mathrm{~min}$ with a constant flow rate of $0.3 \mathrm{~mL} / \mathrm{min}$. This compartment was linked to a Triple TOF $^{\mathrm{TM}} 5600+$ system (AB SCIEX, Concord, NC, Canada) for MS/MS fragmentation spectra. The metabolites were identified by comparing their $\mathrm{m} / \mathrm{z}$ and MS/MS transitions to those recorded in reference databases. Further, the retention time, molecular formula, MZmine ID, and adduct formula were detected.

\subsection{Isolation of Methyl Gallate and Quercetin and HPTLC Analysis}

\subsubsection{Instrumentation}

A CAMAG ${ }^{\circledR}$ (CAMAG, Muttenz, Switzerland) Linomat V was utilized for sample application with adjusted conditions, slit dimension of $6 \mathrm{~mm}$ length and $0.1 \mathrm{~mm}$ width. The plates were developed in a twin-trough chamber. Each band quantification was assessed using a CAMAG TLC Scanner III densitometer and CATS version $4 \mathrm{X}$ software in the absorption mode using a deuterium source.

\subsubsection{General Experimental Procedure}

${ }^{1} \mathrm{H}(400 \mathrm{MHz})$ and ${ }^{13} \mathrm{C}(100 \mathrm{MHz})$ NMR spectra were recorded by a JEOL (Freising, Germany) spectrometer. Both ${ }^{1} \mathrm{H}$ and ${ }^{13} \mathrm{C}$ NMR chemical shifts are expressed in $\delta$ values regarding the solvent peaks $\delta_{\mathrm{H}} 3.31,4.85$ and $\delta_{\mathrm{C}} 49.1 \mathrm{ppm}$ for methanol, while coupling constants are given in Hertz $(\mathrm{Hz})$. The solvents (chloroform $\mathrm{CHCl}_{3}$, ethyl acetate EtOAc, and methanol $\mathrm{MeOH}$ ) of HPLC grade were used for extraction, isolation, and development. The pre-coated silica gel $\mathrm{F}_{254}(0.25 \mathrm{~mm})$ was purchased from Merck Company (Darmstadt, Germany) while silica gel 60/230-400 $\mu \mathrm{m}$ mesh size (Whatman ${ }^{\mathrm{TM}}$, Sanford, ME, USA) was used for column chromatography. Sephadex ${ }^{\circledR}$ LH-20 (Sigma Aldrich, Bremen, Germany) was also utilized.

\subsubsection{Isolation and Purification of Methyl Gallate and Quercetin}

An amount of the total alcoholic plant extract $(13 \mathrm{~g})$ was partitioned with EtOAc, followed by concentration under vacuum to yield $5.7 \mathrm{~g}$ of dry extract. The ethyl acetate extract was chromatographed by silica gel column chromatography using $\mathrm{CHCl}_{3}-\mathrm{MeOH}$ (100:0) up to (60:40), with step-by-step gradient elution, where three sub-fractions were obtained (Pa-EA-1 to Pa-EA-3). The spots were tracked using ferric chloride as a specific spray reagent for methyl gallate and anisaldehyde/sulfuric acid spray reagent for quercetin. The first sub-fraction (Pa-EA-1, 1.2 g) was re-chromatographed on a silica gel column with isocratic elution using $\mathrm{CHCl}_{3}-\mathrm{MeOH}$ (95:5), yielding two sub-fractions (Pa-EA-1-1', PaEA-1-2'). The first one $(0.7 \mathrm{~g})$ was finally purified on a Sephadex LH-20 column eluted with $\mathrm{CHCl}_{3}-\mathrm{MeOH}$ (50:50) to yield $17.4 \mathrm{mg}$ of white powder denoted as compound $\mathbf{1}$. The second subfraction (Pa-EA-2, $3.7 \mathrm{~g}$ ) was re-chromatographed on a silica gel column eluted 
with $\mathrm{CHCl}_{3}-\mathrm{MeOH}$ (85:15) to yield four sub-fractions (Pa-EA-2-1' to Pa-EA-1-4'). The second one ( $1.5 \mathrm{~g}$ ) was finally purified on a Sephadex LH-20 column eluted with $\mathrm{MeOH}$ to yield $31.1 \mathrm{mg}$ of yellow powder denoted as compound 2 .

\subsubsection{HPTLC Analysis}

Preparation of a Standard Solution of Methyl Gallate

An amount of $10 \mathrm{mg}$ of the isolated methyl gallate was used to prepare a methanolic standard stock solution at a concentration of $1 \mathrm{mg} / \mathrm{mL}$. Then, the stock solution was kept in a refrigerator to construct a calibration curve.

\section{Calibration Graph}

According to the requirements of the International Council on Harmonisation (ICH) guidelines [25], different concentrations of the prepared stock solution were applied to a plate with dimensions of $20 \mathrm{~cm} \times 10 \mathrm{~cm}$, each in triplicate with a 6-mm-band length and a distance between bands of $4 \mathrm{~mm}$. The distances from both the $\mathrm{x}$-axis and $\mathrm{y}$-axis were $10 \mathrm{~mm}$. The rate of application used was $15 \mu \mathrm{L} \mathrm{s}^{-1}$, and development of the bands was performed. Different solvent mixtures were used, such as chloroform-ethyl acetate (5:5), chloroform-methanol (9:1), toluene-acetonitrile (7:3), and toluene-acetonitrile (3:7). The solvent mixture consisting of toluene-acetonitrile-glacial acetic acid (3:7:0.5) was found to be the best solvent system with a suitable retention factor $\left(R_{\mathrm{f}}\right)$. Development was performed after saturation for $20 \mathrm{~min}$. The development time was $15 \mathrm{~min}$, the plates were air-dried, and then $R_{\mathrm{f}}$ was calculated to be $0.76 \pm 0.02$. Quantification of the standard zones was assessed at a wavelength of $\lambda=254 \mathrm{~nm}$, and the calibration curve was constructed.

\section{Plant Sample Assay}

For determination of the methyl gallate concentration in the plant extract, $1 \mathrm{~g}$ of the dry extract was dissolved in $5 \mathrm{~mL}$ methanol, transferred to a $100 \mathrm{~mL}$ volumetric flask, and then the volume was adjusted with methanol. Different aliquots of the sample as well as the standard solution of the isolated methyl gallate were spotted under the above-mentioned conditions, and band areas were recorded.

\subsection{In Vivo Study}

\subsubsection{Animals}

Male albino rats, weighing 180-220 g, were obtained from the Egyptian Organization for Biological Products and Vaccines (Vacsera, Dokki, Giza Governorate, Egypt). They were kept in plastic cages with a mesh floor and hardwood bedding under a normal light/dark cycle, with water and food provided ad libitum. Rats were left to acclimatize for one week before the experiments.

\subsubsection{Induction of Diabetes}

After overnight fasting, diabetes was induced by a single intraperitoneal (i.p) dose of STZ (55 mg/ $/ \mathrm{kg}$ ) dissolved in citrate buffer ( $\mathrm{pH}$ 4.5) [26]. Two weeks after STZ administration, blood glucose levels were measured in samples from the tail vein using an Accu-check go blood glucose meter (Roche Diagnostic, Mannheim, Germany). Animals with blood glucose level higher than $300 \mathrm{mg} / \mathrm{dL}$ were considered diabetic and were included in the study.

\subsubsection{Study Design}

Forty rats were divided into five groups (8 animals each). The first group served as normal and received Tween 80. All other groups were insulted with a single (i.p.) dose of STZ ( $55 \mathrm{mg} / \mathrm{kg}$ ). The second group was considered to be control diabetic limb ischemia. The third, fourth, and fifth groups were treated with P. acacia extract $(300 \mathrm{mg} / \mathrm{kg})$, methyl gallate $(100 \mathrm{mg} / \mathrm{kg})$, and quercetin $(100 \mathrm{mg} / \mathrm{kg})$, respectively. The compounds 
were dissolved in Tween 80. Treatment continued daily for four weeks after the onset of diabetes.

\subsubsection{Induction of Hind Limb Ischemia}

Ischemia was induced by the tourniquet method. Rats were anaesthetized by (i.p.) injection of ketamine $(75 \mathrm{mg} / \mathrm{kg}$ ) and xylazine $(7.5 \mathrm{mg} / \mathrm{kg})$ [27]. The tourniquet (rubber band) was looped six times as proximally as possible on the thigh. After $4 \mathrm{~h}$ of ischemia, reperfusion was initiated by releasing the tourniquet [28]. After $24 \mathrm{~h}$ of reperfusion, animals were anaesthetized and sacrificed by cervical dislocation.

\subsubsection{Collection of Tissue Samples}

The gastrocnemius muscles of all rats were removed and divided into two parts. The first part was kept at $-80^{\circ} \mathrm{C}$ for homogenization and the determination of different biochemical parameters. The second part was fixed in $10 \%$ formalin for histopathological investigation.

\subsubsection{Histopathological Investigation}

Samples of the gastrocnemius muscle fixed in formalin were embedded in paraffin. From each block, sections of $3 \mu \mathrm{m}$ thickness were submitted, mounted on a glass slide, stained with hematoxylin and eosin (H\&E), and examined by an independent pathologist. Muscle tissue sections were microscopically evaluated for degenerative changes of myocytes and numbers of inter-bundles capillaries. Capillaries were counted under three different high-power fields (hpf) $(200 \times)$, and the average number was calculated. The severity of microscopic lesions observed was graded based on the degree and extent of tissue damage using a four-point scale [29].

\subsubsection{Biochemical Analysis}

Determination of Levels of the Oxidative Stress and Angiogenesis Markers in the Hind Limb Tissue

All oxidative stress markers were measured in the hind limb tissue homogenate of the studied groups by enzyme-linked immunosorbent assay (ELISA). Malondialdehyde (MDA) levels were measured using a Rat Malondialdehyde ELISA Kit (MyBioSource, San Diego, CA, USA, Catalog No. MBS268427). Reduced glutathione (GSH) levels were measured using a Rat Glutathione (GSH) ELISA Kit (MyBioSource, San Diego, CA, USA, Catalog No. MBS265966). Superoxide dismutase (SOD) levels were measured using a Rat Superoxide Dismutase ELISA Kit (MyBioSource, San Diego, CA, USA, Catalog No. MBS036924), and catalase levels were assessed using a Rat Catalase ELISA Kit (MyBioSource, San Diego, CA, USA, Catalog No. MBS726781), in accordance with the manufacturer's instructions.

Levels of NO and eNOS were assessed in the hind limb tissue lysate of the studied groups by ELISA according to the manufacturer's instructions using a Rat Nitric Oxide (NO) ELISA Kit (MyBioSource, San Diego, CA, USA, Catalog No. MBS3808496) and a Rat Endothelial Nitric Oxide Synthase ELISA Kit (MyBioSource, San Diego, CA, USA, Catalog NO. MBS721860), respectively.

Additionally, levels of HO- 1 and VEGF were determined in the hind limb tissue lysate of the studied groups by a Rat Heme Oxygenase 1 ELISA Kit (MyBioSource, San Diego, CA, USA, Catalog No. MBS764989) and a Rat Vascular Endothelial Growth Factor ELISA Kit (CUSABIO, Houston, TA, USA, Catalog No. MBS724516), respectively.

Determination of the Expression of miRNA-146a, NF- $k$ b, HIF-1 $\alpha$, VEGF, and FGF-2 in the Hind Limb Tissue by Quantitative Real-Time PCR

Total RNA, including miRNA, was extracted from the hind limb tissue of the studied groups using a Qiagen miRNeasy Mini kit (Qiagen, Hilden, Germany, Catalog No. 217004) according to the protocol supplied by the manufacturer. RNA concentration and pu- 
rity were measured spectrophotometrically using a NanoDrop 1000 spectrophotometer (NanoDrop Tech, Wilmington, DE, USA).

MicroRNA-146a expression was measured in two steps using qRT-PCR. A TaqMan ${ }^{\circledR}$ microRNA reverse transcriptase kit (Applied Biosystems, Waltham, MA, USA, Catalog No.4366596) and specific miRNA primers miRNA-146a 5× and RNU6B 5× (Applied Biosystems, Waltham, MA, USA, Catalog No. 4427975) were used for the first step, reverse transcription (RT). RNU6B was used as a housekeeping gene to normalize the miRNA146a expression. RT reactions with a final volume $15 \mu \mathrm{L}$ were made up of $5 \mu \mathrm{L}$ (1-10 ng) of RNA template, $7 \mu \mathrm{L}$ master mix, and $3 \mu \mathrm{L}$ of primer. In a Mastercycler Gradient thermocycler (Eppendorf, Hamburg, Germany), RT was performed as follows: $16^{\circ} \mathrm{C}$ for $30 \mathrm{~min}, 42{ }^{\circ} \mathrm{C}$ for $30 \mathrm{~min}, 85^{\circ} \mathrm{C}$ for $5 \mathrm{~min}$, and then held at $4{ }^{\circ} \mathrm{C}$. The second step, real-time PCR, was carried out in an AB 7500HT instrument with SDS Software version 2.1.1, using TaqMan ${ }^{\circledR}$ Universal Master Mix 40R (Applied Biosystems, Waltham, MA, USA, Catalog No. 4440043) and TaqMan ${ }^{\circledR}$ assays miRNA-146a 20 $\times$ and RNU6B 20× (Applied Biosystems, Waltham, MA, USA, Catalog No. 4427975). The PCR reactions with $20 \mu \mathrm{L}$ final volume consisted of $4 \mu \mathrm{L}$ complementary DNA (cDNA), $10 \mu \mathrm{L} 2 \times$ TaqMan $^{\circledR}$ Universal Master Mix, $1 \mu \mathrm{L} 20 \times$ TaqMan ${ }^{\circledR}$ Gene Expression assay, and $5 \mu \mathrm{L}$ RNase-free water. All reactions were run in duplicate using the following cycling conditions: $95^{\circ} \mathrm{C}$ for $10 \mathrm{~min}$, followed by 40 cycles of $95^{\circ} \mathrm{C}$ for $15 \mathrm{sec}$ and $60^{\circ} \mathrm{C}$ for $1 \mathrm{~min}$.

The expression levels of nuclear factor kappa B (NF-kb), HIF-1 $\alpha$, VEGF, and fibroblast growth factor-2 (FGF-2) were quantified using a GoTaq ${ }^{\circledR}$ 1-Step RT-qPCR System (Promega, Madison, WI, USA, Catalog No. A6020) and glyceraldehyde 3-phosphate dehydrogenase (GAPDH) as a housekeeping gene. The sequences of the primers used and the annealing temperature for each primer are illustrated in Table 1 . The reaction was carried out in a $20 \mu \mathrm{L}$ final volume, including $4 \mu \mathrm{L}$ RNA template, $0.4 \mu \mathrm{L}$ GoScript ${ }^{\mathrm{TM}} \mathrm{RT}$ mix for 1-step RT-qPCR, $1 \mu \mathrm{L}$ of each of the forward and reverse primers, $10 \mu \mathrm{L}$ GoTaq ${ }^{\circledR}$ qPCR master mix, $0.31 \mu \mathrm{L}$ supplemental CXR reference dye, and $3.29 \mu \mathrm{L}$ nuclease-free water. Cycling conditions were $37^{\circ} \mathrm{C}$ for $15 \mathrm{~min}$ for reverse transcription, $95^{\circ} \mathrm{C}$ for $10 \mathrm{~min}$ for inactivation of the reverse transcriptase enzyme, followed by 40 cycles of $95^{\circ} \mathrm{C}$ for $10 \mathrm{sec}$ denaturation, annealing for $30 \mathrm{sec}$ (annealing temperatures are listed in Table 1), and $72{ }^{\circ} \mathrm{C}$ for $30 \mathrm{~s}$ extension. All real-time PCR reactions were performed in a StepOnePlus ${ }^{\mathrm{TM}}$ Real-Time PCR thermal cycling instrument (Applied Biosystems, USA). $\Delta \Delta \mathrm{Ct}$ and fold change were calculated, and the results were expressed as the $\log 2$-fold change relative to the normal group (base line), where the value of the expression in the normal group was normalized to 1 , and $\log 2(1)=$ zero.

Table 1. Primer sequences and annealing temperatures for the measured genes.

\begin{tabular}{cccc}
\hline Gene & Forward Primer & Reverse Primer & Annealing Temperature \\
\hline NF-kb & $5^{\prime}$-CAATGGCTACACAGGACCA-3 & $5^{\prime}$-CACTGTCACCTGGAACCAGA-3 & $55^{\circ} \mathrm{C}$ \\
\hline HIF-1 $\alpha$ & $5^{\prime}$-TGCTTGGTGCTGATTTGTGA-3 ${ }^{\prime}$ & $5^{\prime}$-GGTCAGATGATCAGAGTCCA-3' & $54{ }^{\circ} \mathrm{C}$ \\
\hline VEGF & $5^{\prime}$-AAAAACGAAAGCGCAAGAAA-3 & $5^{\prime}$-TTTCTCCGCTCTGAACAAGG-3 & $51^{\circ} \mathrm{C}$ \\
\hline FGF-2 & $5^{\prime}$-GGCTCTACTGCAAGAACGGC-3 & $5^{\prime}$-GAAACAGTATGGCCTTCTGTC-3 & $53^{\circ} \mathrm{C}$ \\
\hline GAPDH & $5^{\prime}$-ATGACTCTACCCACGGCAAG-3' & $5^{\prime}$-GATCTCGCTCCTGGAAGATG-3' & $55^{\circ} \mathrm{C}$ \\
\hline
\end{tabular}

\subsection{Statistical Analysis}

Data were processed using the Statistical Package for Social Sciences, SPSS (IBM, Armonk, NY, USA), version 21.0 software. The results were expressed as the mean $\pm \mathrm{SD}$. One-way analysis of variance, ANOVA, followed by Bonferroni's post hoc test for multiple comparisons, was employed for statistical analysis. A $P$ value less than 0.05 was considered statistically significant. 


\section{Results and Discussion}

\subsection{Metabolic Analysis Profiling Using LC/ESI-TOF-MS/MS}

Liquid chromatography combined with tandem mass spectrometry (LC-MS/MS) is a modern tool for the detection of natural metabolites that may have beneficial therapeutic effects. Herein, LC-MS/MS of the methanolic crude extract of $P$. acacia is performed for the first time (Figures S1 and S2). This metabolic analysis showed the existence of various chemical classes of natural products such as alkaloids, catechins, flavonoids, flavonoid glycosides, phenolic acids, and minor vitamins and nutrients (Table 2, Figure 1).

Table 2. LC-MS/MS metabolic analysis of the methanolic crude extract of Plicosepalus acacia.

\begin{tabular}{|c|c|c|c|c|c|c|c|c|c|c|c|}
\hline No. & $\begin{array}{l}\text { Polarity } \\
\text { Mode }\end{array}$ & $\begin{array}{l}\text { MZmine } \\
\text { ID }\end{array}$ & $\begin{array}{l}\text { Ret. } \\
\text { Time } \\
\text { (min) }\end{array}$ & $\begin{array}{l}\text { Measured } \\
m / z\end{array}$ & $\begin{array}{l}\text { Calculated } \\
m / z\end{array}$ & $\begin{array}{l}\text { Mass } \\
\text { Error } \\
(\mathrm{ppm})\end{array}$ & Adduct & $\begin{array}{l}\text { Molecular } \\
\text { For- } \\
\text { mula }\end{array}$ & $\begin{array}{c}\text { MS/MS } \\
\text { Spectrum }\end{array}$ & $\begin{array}{l}\text { Deduced } \\
\text { Compound }\end{array}$ & Ref. \\
\hline \multicolumn{12}{|c|}{ Alkaloids } \\
\hline 1 & Positive & 83 & 1.37 & 138.0543 & 138.0555 & -8.69 & {$[\mathrm{M}+\mathrm{H}]^{+}$} & $\mathrm{C}_{7} \mathrm{H}_{7} \mathrm{NO}_{2}$ & 138,94 & Trigonelline & [30] \\
\hline 2 & Positive & 167 & 4.94 & 195.0876 & 195.0882 & -3.08 & {$[\mathrm{M}+\mathrm{H}]^{+}$} & $\mathrm{C}_{8} \mathrm{H}_{10} \mathrm{~N}_{4} \mathrm{O}_{2}$ & 195,138 & Caffeine & [31] \\
\hline \multicolumn{12}{|c|}{ Catechins } \\
\hline 3 & Negative & 272 & 4.63 & 289.0717 & 289.0712 & 1.73 & {$[\mathrm{M}-\mathrm{H}]^{-}$} & $\mathrm{C}_{15} \mathrm{H}_{14} \mathrm{O}_{6}$ & $289,245,205,179$ & $(-)$-Epicatechin & [32] \\
\hline \multicolumn{12}{|c|}{ Phenolic Acids } \\
\hline 4 & Negative & 108 & 1.21 & 153.0192 & 153.0188 & 2.61 & {$[\mathrm{M}-\mathrm{H}]^{-}$} & $\mathrm{C}_{7} \mathrm{H}_{6} \mathrm{O}_{4}$ & 153,109 & Protocatechuic acid & [33] \\
\hline 5 & Negative & 326 & 6.86 & 167.0343 & 167.0344 & -0.60 & {$[\mathrm{M}-\mathrm{H}]^{-}$} & $\mathrm{C}_{9} \mathrm{H}_{8} \mathrm{O}_{2}$ & $167,152,124,108$ & Vanillic acid & [34] \\
\hline 6 & Positive & 657 & 9.36 & 181.0516 & 181.0501 & 8.82 & {$[\mathrm{M}+\mathrm{H}]^{+}$} & $\mathrm{C}_{9} \mathrm{H}_{8} \mathrm{O}_{4}$ & 181,163 & Caffeic acid & [35] \\
\hline \multicolumn{12}{|c|}{ Flavonoids and Their Glycosides } \\
\hline 7 & Negative & 307 & 6.26 & 609.1453 & 609.1456 & -0.49 & {$[\mathrm{M}-\mathrm{H}]^{-}$} & $\mathrm{C}_{27} \mathrm{H}_{30} \mathrm{O}_{16}$ & 609,300 & Rutin & [35] \\
\hline 8 & Negative & 314 & 6.50 & 303.0504 & 303.0505 & -0.33 & {$[\mathrm{M}-\mathrm{H}]^{-}$} & $\mathrm{C}_{15} \mathrm{H}_{12} \mathrm{O}_{7}$ & 303,285 & Taxifolin & [36] \\
\hline 9 & Negative & 318 & 6.57 & 593.1569 & 593.1506 & 10.62 & {$[\mathrm{M}-\mathrm{H}]^{-}$} & $\mathrm{C}_{27} \mathrm{H}_{29} \mathrm{O}_{15}$ & 593,285 & Datiscin & [37] \\
\hline 10 & Positive & 305 & 6.71 & 611.1911 & 611.1976 & -10.63 & {$[\mathrm{M}+\mathrm{H}]^{+}$} & $\mathrm{C}_{28} \mathrm{H}_{34} \mathrm{O}_{15}$ & 611,303 & Hesperidin & [38] \\
\hline 11 & Negative & 339 & 7.22 & 447.0945 & 447.0927 & 4.03 & {$[\mathrm{M}-\mathrm{H}]^{-}$} & $\mathrm{C}_{21} \mathrm{H}_{20} \mathrm{O}_{11}$ & 447,300 & Quercetrin & [37] \\
\hline 12 & Negative & 488 & 9.51 & 301.0359 & 301.0348 & 3.65 & {$[\mathrm{M}-\mathrm{H}]^{-}$} & $\mathrm{C}_{15} \mathrm{H}_{9} \mathrm{O}_{7}$ & 301,151 & Quercetin & [35] \\
\hline 13 & Negative & 528 & 10.03 & 271.0607 & 271.0606 & 0.37 & {$[\mathrm{M}-\mathrm{H}]^{-}$} & $\mathrm{C}_{15} \mathrm{H}_{12} \mathrm{O}_{5}$ & $271,177,151,119$ & Naringenin & [39] \\
\hline 14 & Negative & 558 & 10.48 & 269.0465 & 269.0450 & 5.58 & {$[\mathrm{M}-\mathrm{H}]^{-}$} & $\mathrm{C}_{15} \mathrm{H}_{10} \mathrm{O}_{5}$ & 269,151 & Apigenin & [35] \\
\hline 15 & Positive & 863 & 10.62 & 303.0886 & 303.0869 & 5.61 & {$[\mathrm{M}+\mathrm{H}]^{+}$} & $\mathrm{C}_{16} \mathrm{H}_{14} \mathrm{O}_{6}$ & 303,151 & Hesperetin & [40] \\
\hline 16 & Positive & 975 & 11.42 & 301.0736 & 301.0712 & 7.97 & {$[\mathrm{M}+\mathrm{H}]^{+}$} & $\mathrm{C}_{16} \mathrm{H}_{12} \mathrm{O}_{6}$ & 301,286 & Diosmetin & [41] \\
\hline \multicolumn{12}{|c|}{ Miscellaneous compounds } \\
\hline 17 & Positive & 33 & 1.19 & 104.1066 & 104.1070 & -3.84 & {$[\mathrm{M}]^{+}$} & $\mathrm{C}_{5} \mathrm{H}_{14} \mathrm{NO}$ & 104,60 & Choline & [42] \\
\hline 18 & Positive & 37 & 1.24 & 162.1115 & 162.1130 & -9.25 & {$[\mathrm{M}+\mathrm{H}]^{+}$} & $\mathrm{C}_{7} \mathrm{H}_{15} \mathrm{NO}_{3}$ & $162,103,85$ & Carnitine & [43] \\
\hline 19 & Positive & 141 & 1.73 & 124.0386 & 124.0399 & -10.48 & {$[\mathrm{M}+\mathrm{H}]^{+}$} & $\mathrm{C}_{6} \mathrm{H}_{5} \mathrm{NO}_{2}$ & 124,80 & Nicotinic acid & [30] \\
\hline 20 & Negative & 281 & 4.90 & 183.0309 & 183.0293 & 8.74 & {$[\mathrm{M}-\mathrm{H}]^{-}$} & $\mathrm{C}_{8} \mathrm{H}_{8} \mathrm{O}_{5}$ & $183,140,124$ & Methyl gallate & [44] \\
\hline
\end{tabular}

Obviously, the methanolic extract of $P$. acacia is a rich source of polyphenolic compounds that are correlated with the reported antioxidant and anti-inflammatory effects of $P$. acacia [45]. The detected natural products were identified based on their mass accuracy expressed in parts per million (ppm) in addition to matching their fragmentation pattern or MS/MS ion transitions with that reported in literature [46]. Polyphenols have free radical scavenging, antioxidant, anti-aging, hepatoprotective, and reno-protective activities $[47,48]$. The antioxidant activity of quercetin, taxifolin, catechin, hesperetin, and naringenin was previously assessed through their capability to perform hydrogen peroxide scavenging activity, their lower metal-reducing ability, and their lipid peroxidation inhibitory activity [49]. The hypolipidemic and hypoglycemic effects of quercetin were reported through its ability to ameliorate insulin resistance, lower plasma triglyceride levels, and reduce liver fat accumulation [50]. Flavonoids acts as anti-neoplastic agents through their antioxidant activity, carcinogen scavenging, antiproliferation, apoptosis induction, inhibition of angiogenesis, and weakening of chemotherapeutic agents' resistance [51]. On the other hand, trigonelline alkaloid and protocatechuic acid showed hypoglycemic, antimicrobial, anti-tumor, and anti-inflammatory activities [52,53]. Further, L-carnitine acts as a fat burner that induces 
the metabolism of lipids and decreases the serum LDL-cholesterol level without any effect on the HDL-cholesterol level [54]. Finally, the antioxidant, free radical scavenging, antiinflammatory, and hypoglycemic therapeutic effects of the crude extract of P. acacia may be correlated with the metabolites detected in the current study.<smiles></smiles>

1<smiles>Cn1c(=O)c2c(ncn2C)n(C)c1=O</smiles><smiles>Oc1cc(O)c2c(c1)OC(c1ccc(O)c(O)c1)C(O)C2</smiles>

3<smiles>O=C(O)c1ccc(O)c(O)c1</smiles>

4<smiles>COc1cc(C(=O)O)ccc1O</smiles>

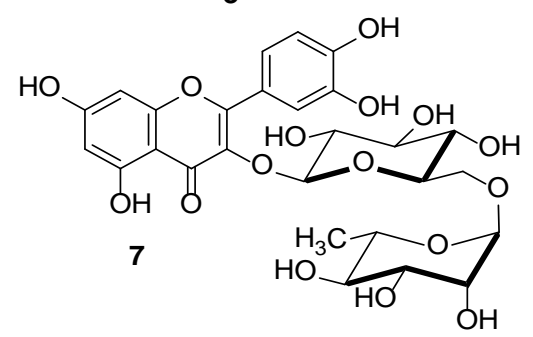<smiles>O=C1c2c(O)cc(O)cc2O[C@H](c2ccc(O)c(O)c2)C1O</smiles>

6

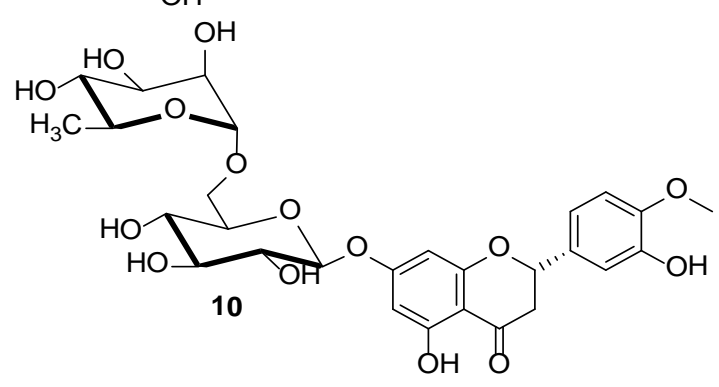

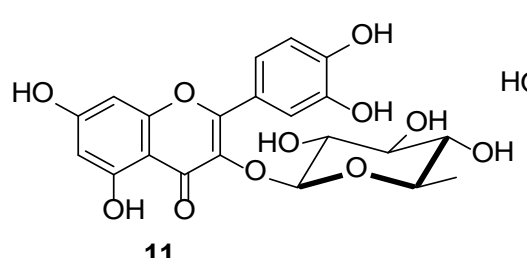

11<smiles>O=c1c(O)c(-c2ccc(O)c(O)c2)oc2cc(O)cc(O)c12</smiles>

12<smiles>O=C1CC(c2ccc(O)cc2)Oc2cc(O)cc(O)c21</smiles>

13<smiles>O=c1cc(-c2ccc(O)cc2)oc2cc(O)cc(O)c12</smiles>

14<smiles>COc1ccc([C@H]2CC(=O)c3c(O)cc(O)cc3O2)cc1O</smiles>

15<smiles>COc1ccc(-c2cc(=O)c3c(O)cc(O)cc3o2)cc1O</smiles>

16<smiles>C[N+](C)(C)CCO</smiles>

17<smiles>C[N+](C)(C)CC(O)CC(=O)[O-]</smiles>

18<smiles>O=C(O)c1cccnc1</smiles>

19<smiles>COC(=O)c1cc(O)c(O)c(O)c1</smiles>

20

Figure 1. Chemical structures of the detected metabolites using LC-MS/MS, trigonelline (1), caffeine (2), epicatechin (3), protocatechuic acid (4), vanillic acid (5), caffeic acid (6), rutin (7), taxifolin (8), datiscin (9), hesperidin (10), quercetrin (11), quercetin (12), naringenin (13), apigenin (14), hesperetin (15), diosmetin (16), choline (17), carnitine (18), nicotinic acid (19) and methyl gallate (20). 


\subsection{Identification of the Isolated Compounds}

Compound 1 (Figure 2) was obtained as a white powder, and its molecular formula was determined to be $\mathrm{C}_{8} \mathrm{H}_{9} \mathrm{O}_{5}$ by ESI-MS with $m / z 185[\mathrm{M}+\mathrm{H}]{ }^{+}$. The ${ }^{13} \mathrm{C}$ NMR spectral data (Figure S3): $\delta_{\mathrm{C}} 52.3\left(\mathrm{OCH}_{3}\right), 110.0(\mathrm{C}-2,6), 121.4(\mathrm{C}-1), 139.7$ (C-4), $146.4(\mathrm{C}-3,5), 168.9$ $(\mathrm{C}=\mathrm{O})$. The ${ }^{1} \mathrm{H}$ NMR spectral data (Figure $\left.\mathrm{S} 4\right): \delta_{\mathrm{H}} 3.80\left(\mathrm{OCH}_{3}, \mathrm{~s}\right), 7.05(2 \mathrm{H}, \mathrm{s}, \mathrm{H}-2,6)$. The combined spectral data together with comparison of the data previously reported in the literature [21] confirmed the structure of compound $\mathbf{1}$ as methyl gallate.<smiles>COC(=O)c1cc(O)c(O)c(O)c1</smiles>

1<smiles>O=c1c(O)c(-c2ccc(O)c(O)c2)oc2cc(O)cc(O)c12</smiles>

2

Figure 2. Chemical structures of the isolated methyl gallate (1) and quercetin (2).

Compound 2 (Figure 2) was obtained as a yellow powder, and its molecular formula was determined to be $\mathrm{C}_{15} \mathrm{H}_{10} \mathrm{O}_{7}$ by ESI-MS with $m / z 301[\mathrm{M}-\mathrm{H}]^{-}$. Compound 2 was identified as quercetin, which was compared with a standard.

\subsection{HPTLC Analysis for Quantification of Methyl Gallate}

\subsubsection{Linearity}

The linearity of the HPTLC method was evaluated by analyzing different six concentrations of the isolated methyl gallate as a standard solution, each in triplicate (Figure $3 \mathrm{~A}$ ). A good linear relationship was shown over the concentration range of 4-40 $\mu \mathrm{g}$ per band with respect to the area. The correlation coefficient $\left(R^{2}\right)$ was 0.966 , and the linear regression equation was found to be $y=910.96 x+20,008$, where $y$ is the spot area, and $x$ is the concentration of methyl gallate.

\subsubsection{System Precision}

The system precision was checked by determination of a selected concentration $(2 \mathrm{mg} / \mathrm{mL})$, applied as a $4 \mu \mathrm{g} / \mathrm{band}$ of the methyl gallate where it was applied in triplicate. The value of the percent relative standard deviation (\%RSD) was calculated to be 2.52 and 1.44 , respectively, indicating the precision (Table 3 ).

Table 3. Validation parameters of the HPTLC method for the determination of methyl gallate scanned at $\lambda=254 \mathrm{~nm}$.

\begin{tabular}{cc}
\hline Parameter & Results \\
\hline Linearity range $(\mu$ g per band) & $4-40$ \\
Correlation coefficient $\left(\mathrm{R}^{2}\right)$ & 0.966 \\
Regression equation & $\mathrm{Y}=910.69 \mathrm{X}+20,008$ \\
Limit of detection $(\mu \mathrm{g}$ per band) & 0.4893 \\
Limit of quantification ( $\mu$ g per band) & 1.6310 \\
System precision (\%RSD) & 2.52 \\
Method precision $(\% R S D)$ & 1.14 \\
\hline
\end{tabular}




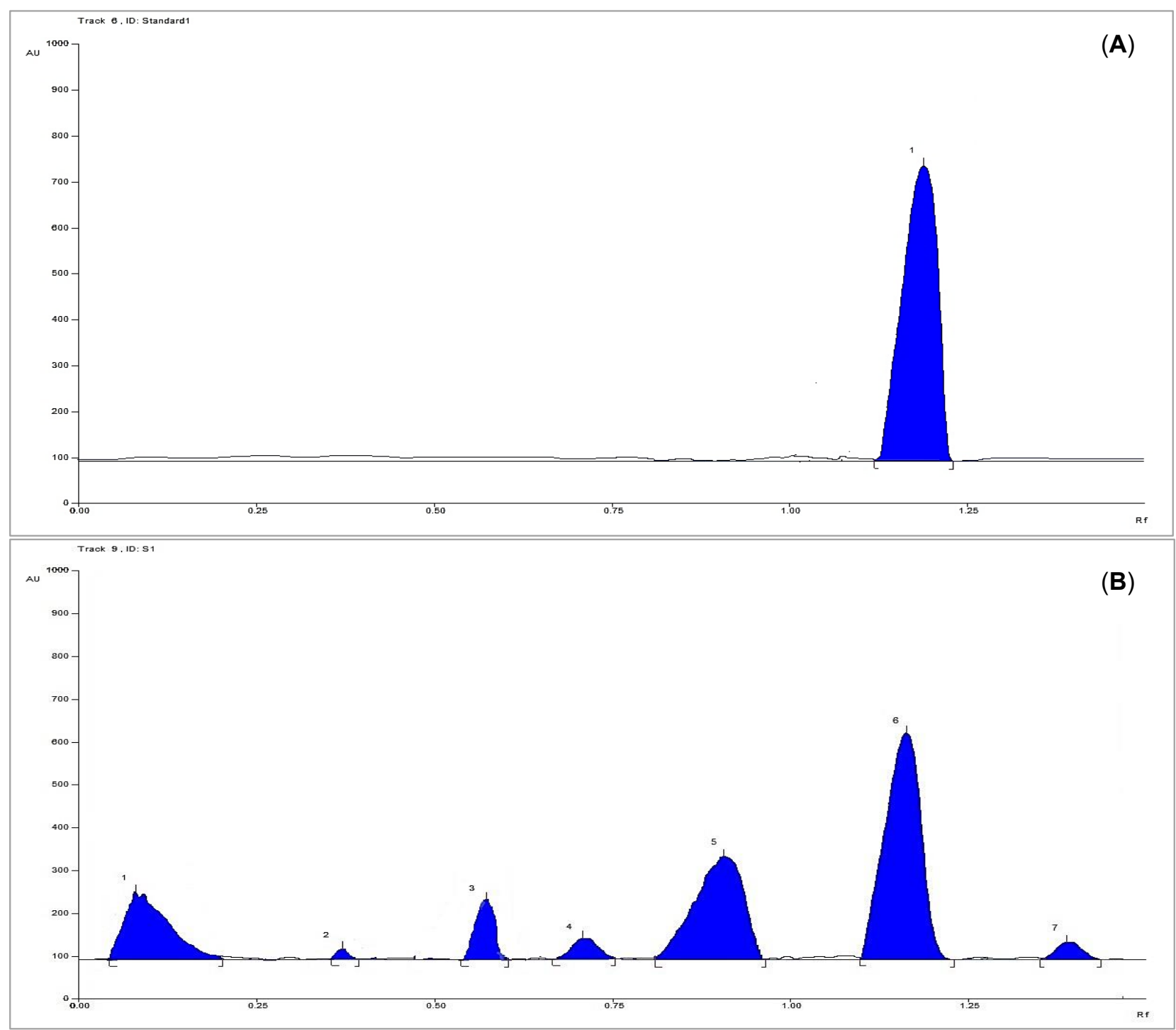

Figure 3. (A) HPTLC chromatogram of $6 \mu \mathrm{g}$ per band of standard methyl gallate scanned at $\lambda=254 \mathrm{~nm}$, (B) HPTLC chromatogram of $300 \mu \mathrm{g}$ per band of the plant extract scanned at $\lambda=254 \mathrm{~nm}$.

\subsubsection{Method Precision}

The plant extract was applied six times under the same above-mentioned procedure to ensure the method precision. The low value of \%RSD (1.14) indicated the precision of the method (Table 3).

\subsubsection{Accuracy}

The accuracy of the proposed method was determined by mixing of the pre-analyzed sample with a certain concentration of standard methyl gallate solution, and then, the fortified sample was investigated under the same above-mentioned procedure. The results illustrated in Table 3 indicated the accuracy of the procedure.

\subsubsection{Limits of Detection and Quantification}

The computation of both the limit of detection and the limit of quantification were assessed according to the following equations: $3 \sigma / \mathrm{S}$ and $10 \sigma / \mathrm{S}$, respectively, where $\sigma$ is the standard deviation of the response and $S$ is the slope of the calibration curve. The data are listed in Table 3. 


\subsubsection{Analytical Solution Stability}

The analytical procedure was repeated after storage of the standard solution either at $4{ }^{\circ} \mathrm{C}$ for 10 days or at ambient temperature for two days to ensure the stability of the solutions under these conditions.

\subsubsection{Sample Analysis}

The proposed method was applied for the determination of methyl gallate in the plant extract, which was applied as bands in triplicate (Figure 3B). The concentration of the sample was defined based on the regression equation, where the concentration was found to be $1.7 \mathrm{mg} / 100 \mathrm{mg}$ of plant dry extract.

\subsection{In Vivo Study}

\subsubsection{Histopathological Changes in the Study Groups}

In the current study, a rat model of type 1 diabetes mellitus with hind limb ischemia was developed. This model is used widely to conduct experimental studies on PAD that is considered one of the most common complications of diabetes. It is one of the most essential models to study therapeutic angiogenesis and/or arteriogenesis [55], which is the focus of our study.

Histopathological examination of the hind limb muscle in the study groups revealed that the muscles of the normal group showed a normal bundle of skeletal muscle fibers (arrow heads) separated by thick fibrous seta containing blood vasculature (arrow) (Figure 4A). Muscle tissue of the control diabetic limb ischemia group displayed separation of bundles, degenerated necrotic muscle bundles with no identified nuclei (Black arrows), interstitial edema (Red arrows), and chronic inflammatory cells (Arrow heads) (Figure 4B). In comparison to the control group, some compact muscle bundles, degenerated necrotic muscle bundles with no identified nuclei (Black arrows), intermuscular edema (Red arrows), hemorrhage (Yellow arrow) congested vessel (Blue arrow), and chronic inflammatory cells (Arrow heads) were observed in the group treated with the P. acacia extract (Figure 4C). The group treated with methyl gallate showed uniform muscle bundles with mild interstitial edema and hemorrhage (Black arrows). Very few inflammatory cells (Arrow heads) were seen, but no degenerated or necrotic muscle cells (Figure 4D). The group treated with quercetin presented uniform muscle bundles with mild interstitial edema (Black arrows) (Figure 4E).

The number of intermuscular capillaries was significantly decreased in the control limb ischemia group compared to normal. Treatment with methyl gallate and quercetin displayed significant increases in numbers of intermuscular capillaries compared to the control limb ischemia and P. acacia extract groups (Figure 4F). The increase in the number of intermuscular capillaries/vessels indicates enhanced therapeutic angiogenesis in hind limb ischemia models $[56,57]$. 
$A$

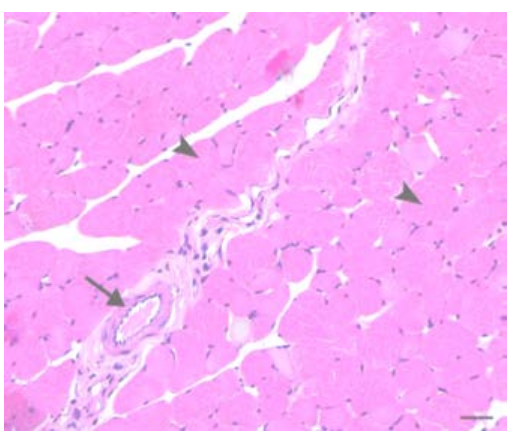

$D$

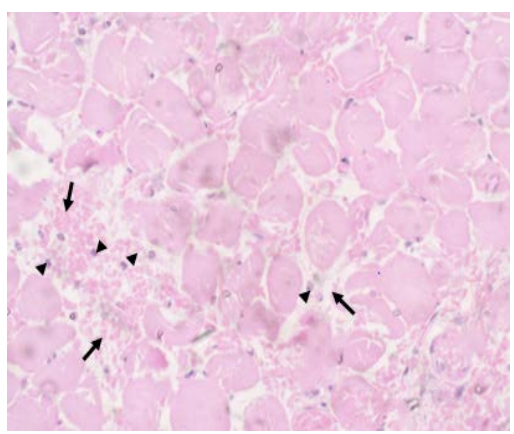

$B$

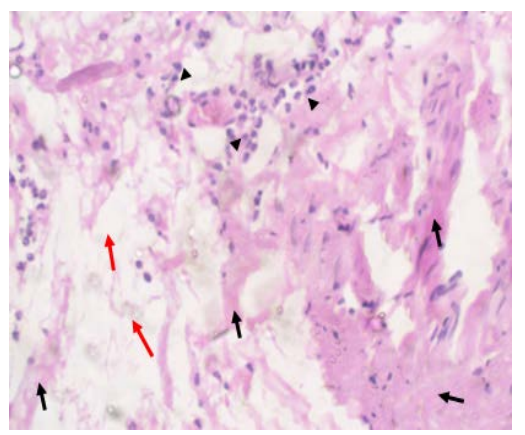

$E$
C

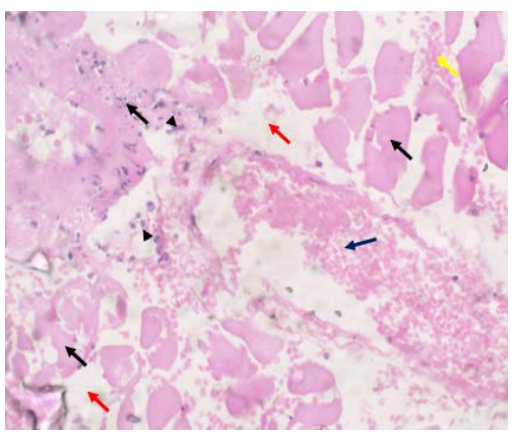

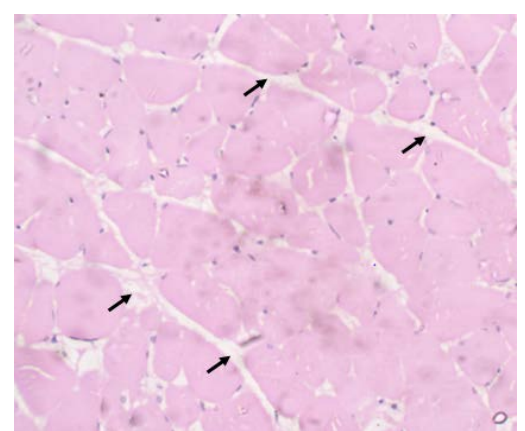

$F$

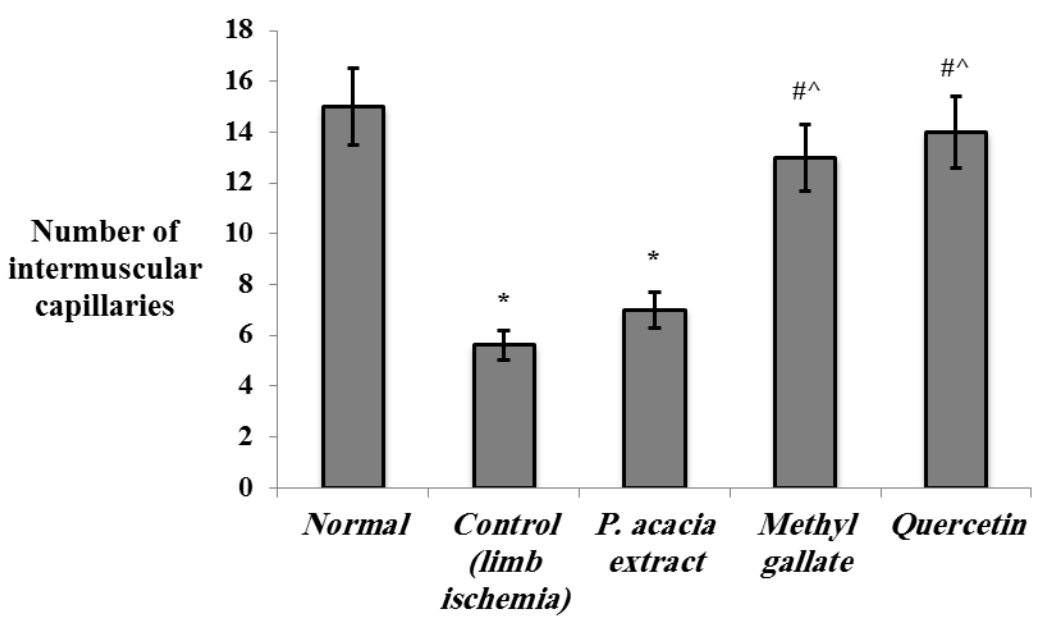

Figure 4. Histopathological investigation of the effects of the P. acacia extract and its isolated compounds (methyl gallate and quercetin) on the gastrocnemius muscle in the experimental rats. (A) normal group, (B) hind limb ischemia control group, (C) P. acacia extract-treated group, (D) methyl gallate-treated group, and (E) quercetin-treated group. (F) Bar charts representing the count of intermuscular capillaries. Data are expressed as the mean \pm SD. Data were analyzed using one-way ANOVA followed by Bonferroni's post hoc test. * Significantly different compared to the normal group, ${ }^{\#}$ significantly different compared to the hind limb ischemia control group, ^ significantly different compared to the group treated with the P. acacia extract. Values were considered significantly different at $p<0.05$.

Examined muscle tissues of the study groups were graded according to the presence of interstitial edema, hemorrhage, myocyte vacuolization, myocyte necrosis, mononuclear cell infiltration, and fibrosis (Table 4). Degenerative changes, edema, hemorrhage, and inflammation were marked in the control hind limb ischemia muscles but were moderate 
in the group treated with the P. acacia extract. Methyl gallate-treated groups exhibited mild edema, hemorrhage, and inflammation with no degenerative changes. Absence of degenerative changes and inflammation with minimal edema were detected in the group treated with quercetin (Table 4).

Table 4. Histopathological features of the examined muscle tissues.

\begin{tabular}{cccccc}
\hline $\begin{array}{c}\text { Histopathological } \\
\text { Features }\end{array}$ & Normal & $\begin{array}{c}\text { Control (Limb } \\
\text { Ischemia) }\end{array}$ & P. acacia & Methyl Gallate & Quercetin \\
\hline Degenerative changes & None & Marked (Grade 4) & Moderate (Grade 3) & None & None \\
\hline Edema, hemorrhage & None & Marked (Grade 4) & Moderate (Grade 3) & $\begin{array}{c}\text { Mild hemorrhage } \\
\text { (Grade 2) }\end{array}$ & $\begin{array}{c}\text { Minimal edema } \\
\text { (Grade 1) }\end{array}$ \\
\hline Inflammation & None & Marked (Grade 4) & Moderate (Grade 3) & Mild (Grade 2) & None \\
\hline
\end{tabular}

3.4.2. Effect of Treatment with the P. acacia Extract, Methyl Gallate and Quercetin on the Investigated Biochemical Parameters

The hypoxia that accompanies hind limb ischemia has a strong influence on the biochemical processes in the affected tissue. It induces the generation of reactive oxygen species (ROS) [58] and leads to the development of oxidative stress, a major signal in ischemia/reperfusion injury [59]. Oxidative stress plays an essential role during angiogenesis. Physiological or pathological angiogenesis originates by tissue demands for oxygen and nutrients leading to a hypoxia/reoxygenation cycle [60]. Studies have shown that situations of hypoxia followed by reoxygenation accelerate tubular morphogenesis in human microvascular endothelial cells and encourage angiogenesis in animal models [61].

The main mechanism of oxidative stress-induced angiogenesis involves HIF/VEGF signaling [60]. ROS-mediated angiogenesis is strongly connected with VEGF expression [62]. Moreover, ROS affect VEGF-stimulated VEGFR2 dimerization and autophosphorylation, which are required for VEGFR2 activation and subsequent angiogenesis [63]. Similarly, products of oxidation are reported to interact with VEGFR2 and thus stimulate angiogenesis [64]. The augmentation of angiogenesis by oxidation products was attributed to activation of the HIF/VEGF pathway [65]. HIF-1 $\alpha$ inhibition abrogates the proangiogenic effect of oxidized products in vivo, suggesting that the HIF- $1 \alpha$ pathway is a possible molecular mechanism by which they induce angiogenesis [66].

Additionally, VEGF signaling through VEGFR2 promotes eNOS activity through multiple mechanisms. eNOS produces NO, an important vasodilator that rapidly diffuses throughout the endothelium. NO activates the enzyme soluble guanylate cyclase (sGC) to produce cyclic guanosine monophosphate (cGMP). This particular part of the eNOS signaling pathway contributes to both an acute vasodilating effect in the neighboring vascular smooth muscle cells (VSMCs) and the long-term angiogenic functions of ECs, such as proliferation [67].

Studies have also shown other mechanisms of ROS-activated angiogenesis that operate in a VEGF-independent manner. One of those mechanisms includes the formation of new lipid oxidation products with proangiogenic activities. These products function through activation of the toll-like receptor (TLR)2/MyD88 pathway, leading to the activation of Rac1 to stimulate cell migration and angiogenesis [68]. Another study reported that peroxidized unsaturated fatty acids stimulate TLR4 signaling in endothelial cells, leading to NF- $\mathrm{B}$ activation [69]. Under most conditions, angiogenesis is closely related to the mobilization of inflammatory cells. During physiological or repair processes, the inflammation process is transient and acts as a substantial source of ROS [70]. In addition, TLR signaling has been shown to affect the HIF/VEGF pathway of angiogenesis. TLR2 modulates the expression of HIF-1 $\alpha$, which activates the VEGF promoter in response to hypoxia [71].

In the current work, levels of MDA were elevated in the skeletal muscles of the hind limb ischemia of untreated rats, with a significant reduction of the levels of GSH, SOD, and catalase $(p<0.001)$. Treatment with the extract of $P$. acacia, methyl gallate, and quercetin 
significantly decreased levels of MDA and enhanced levels of GSH, SOD, and catalase in the muscle relative to the control lower limb ischemia group. The improved oxidative profile was more significantly detected in the groups that were treated with isolated quercetin and methyl gallate compared to the group treated with the P. acacia extract (Figure 5).

A

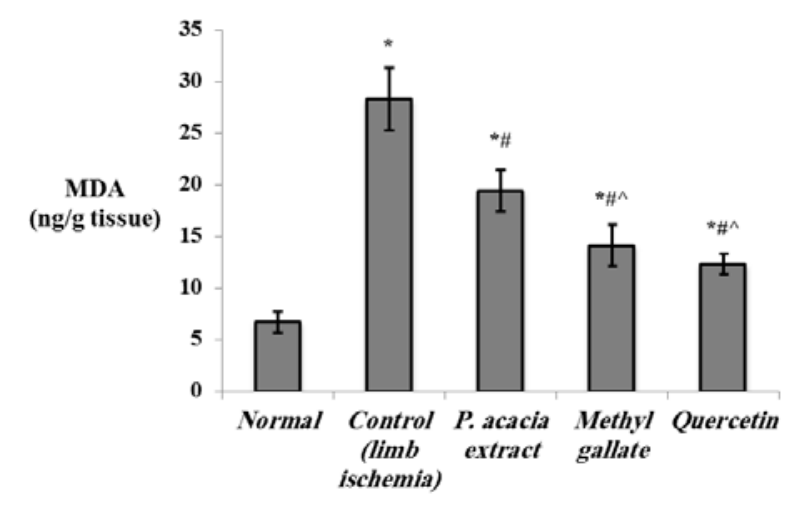

C

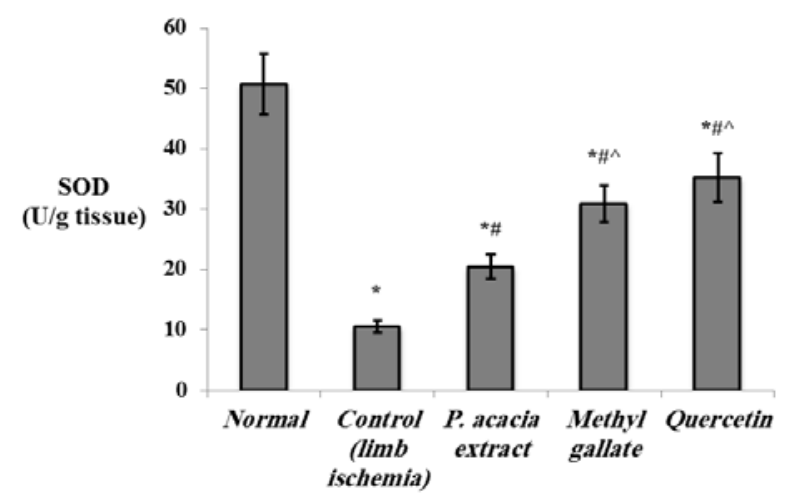

B

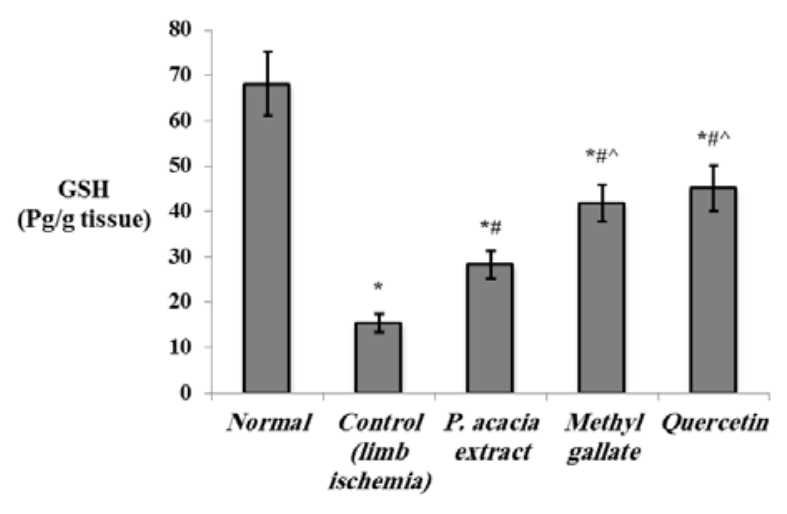

D

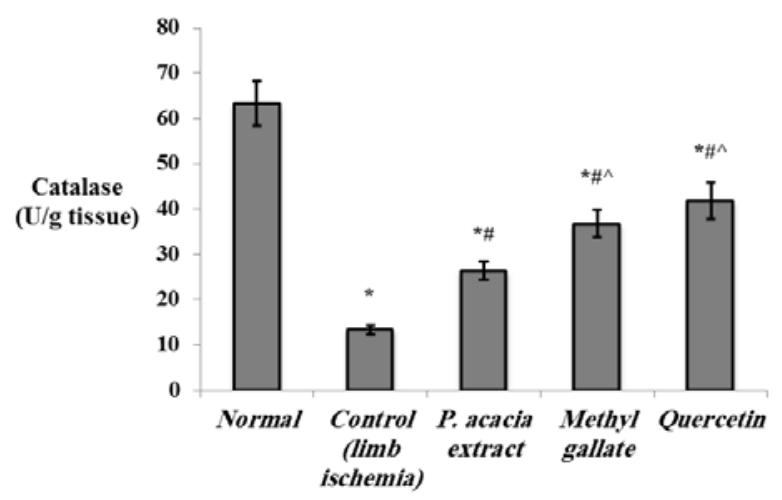

Figure 5. The effect of the P. acacia extract and its isolated compounds (methyl gallate and quercetin) on the levels of (A) MDA, (B) GSH, (C) SOD enzyme, and (D) catalase enzyme in the hind limb tissue of the experimental rats $(n=8)$. $\mathrm{MDA}=$ malondialdehyde; $\mathrm{GSH}=$ reduced glutathione; $\mathrm{SOD}=$ superoxide dismutase. Data are expressed as the mean $\pm \mathrm{SD}$ and were analyzed using one-way ANOVA followed by Bonferroni's post hoc test. * Significantly different compared to the normal group, " significantly different compared to the hind limb ischemia control group, ^ significantly different compared to the group treated with the P. acacia extract. Values were considered significantly different at $p<0.05$.

Lipid peroxidation, indicated by MDA, was reported to increase in the muscle of the limb ischemia/reperfusion model [72]. Reduced levels of GSH were also observed in hind limb ischemia-reperfusion injury in mice [73]. On the other hand, overexpression of catalase prevented the high fat diet-induced ischemic limb necrosis, myopathy, and mitochondrial dysfunction [74]. Similarly, overexpression of extracellular SOD was shown to protect against brain injury induced by chronic hypoxia [75].

Treatment with methyl gallate and quercetin in the present study restored the levels of the antioxidant enzymes and alleviated the oxidative stress in the hind limb ischemia muscle. The antioxidant capabilities of the studied compounds are well-established. The antioxidant properties of methyl gallate were proved in various studies [76-79]. Methyl gallate was reported to be a potent antioxidant that inhibits oxidative stress in human adipocytes [80]. The antioxidant capabilities of methyl gallate also helped to attenuate doxorubicin-induced cardiotoxicity in rats [81].

The antioxidant activities of quercetin have been studied extensively and have potentiated its use in several medicinal applications [82]. Quercetin therapy was reported to increase 
GSH levels and enhance the antioxidant capacity in rats with renal ischemia/reperfusion injury [83]. Quercetin was also reported to protect against lipopolysaccharide-induced toxicity by increasing the levels of SOD and catalase and reducing the levels of MDA [84,85].

Additionally, the current results revealed that the levels of NO and eNOS were significantly decreased in the hind limb ischemia muscles compared to the normal group $(p<0.001)$. Both NO and eNOS were significantly improved by treatment with P. acacia, methyl gallate or quercetin. Notably, levels of NO and eNOS in the hind limb ischemia muscles of the groups that received methyl gallate and quercetin were significantly higher than the levels in the group treated with P. acacia (Figure 6).

A

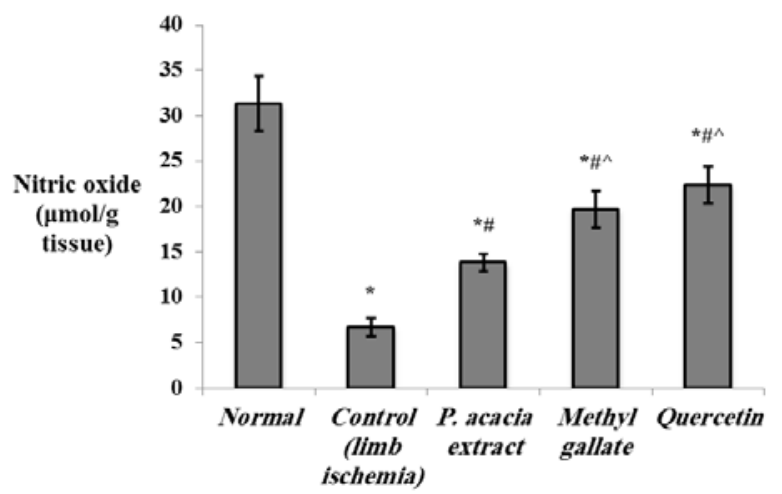

B

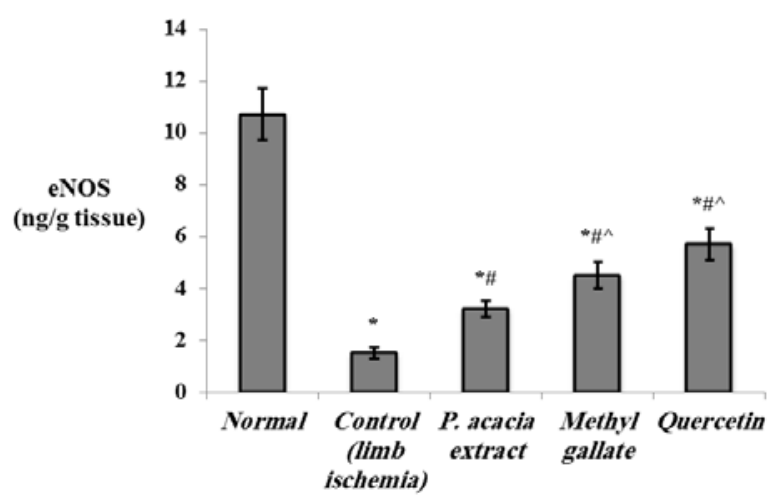

Figure 6. The effect of the P. acacia extract and its isolated compounds (methyl gallate and quercetin) on the levels of (A) nitric oxide, and (B) eNOS in the hind limb tissue of the experimental rats $(n=8)$. eNOS = endothelial nitric oxide synthase. Data are expressed as the mean \pm SD and were analyzed using one-way ANOVA followed by Bonferroni's post hoc test. * Significantly different compared to the normal group, ${ }^{\#}$ significantly different compared to the hind limb ischemia control group, ^ significantly different compared to the group treated with the $P$. acacia extract. Values were considered significantly different at $p<0.05$.

The expression of eNOS was previously shown to be significantly reduced in the endothelial cells of mice/rats with chronic hind limb ischemia [86,87]. The angiogenic activity of $\mathrm{NO}$ has been used in the regeneration of damaged tissue. Recently, pharmaceutical formulations that release $\mathrm{NO}$ in controlled doses were applied to enhance the process of angiogenesis [88]. In particular, a NO releasing hydrogel has been documented to enhance the therapeutic effects of mesenchymal stem cell therapy for hind limb ischemia [89]. In this context, overexpression of eNOS was reported to be protective against ischemia/reperfusion injury [90]. The eNOS-derived NO was proven to be essential for both early and late vascular recovery in response to hind limb ischemia [91]. In the current study, the enhancement of the levels of NO and eNOS was most pronounced in the group treated with quercetin. In agreement, quercetin was shown to improve endothelial function by inducing eNOS activity in human aortic endothelial cells [92]. Quercetin rapidly phosphorylates eNOS through a cAMP/protein kinase A (PKA)-mediated pathway to enhance the release of $\mathrm{NO}$ and to induce vasodilation [93].

The current study showed that the levels of HO-1 and VEGF in the ischemic muscles (Figure 7), as well as the gene expression levels of HIF-1 $\alpha$, VEGF, and FGF-2 (Figure 8), were significantly elevated in the control lower limb ischemia untreated rats $(p<0.001)$. The levels of all those markers were further upregulated in all treated groups, with the highest levels observed in quercetin-treated rats. In contrast, the expression of NF- $k B$ was significantly elevated in the control lower limb ischemia group vs. the normal group $(p<0.001)$. Treatment with the extract of P. acacia, methyl gallate, and quercetin significantly downregulated the expression of NF- $\mathrm{KB}$ in the lower limb ischemic muscles compared to the control group. This downregulation was most obvious in the quercetin-treated group, where the expression levels of NF- $\mathrm{KB}$ in were significantly lower than in the two other treated groups (Figure 8). 
HO-1 is a rate-limiting enzyme that catalyzes oxidative degradation of heme to iron, biliverdin, and carbon monoxide. It is induced under stressful conditions, involving hypoxia [94]. HO-1 is a downstream target of the hypoxia-inducible transcription factor HIF- $1 \alpha$, the key regulator of the body's response to hypoxia [95]. It was recently reported that skeletal muscle HO-1 stabilizes HIF- $1 \alpha$ through its carbon monoxide product and promotes effective glucose utilization to protect against ischemia-mediated tissue injury and necrosis [96]. The protective role of HO-1 against other types of ischemia such as renal [97] and myocardial ischemia [98] by reducing oxidative stress has also been documented. Moreover, $\mathrm{HO}-1$ has been identified as an important player in cellular defense against stressful conditions. HO-1 protects endothelial cells from apoptosis, regulates vascular tone, relaxes blood vessels, attenuates inflammatory responses in the vessel wall, and participates in blood vessel formation via angiogenesis and vasculogenesis [99].

Upregulation of the pro-angiogenic factors (VEGF and FGF-2) as well as HIF- $1 \alpha$ and HIF- $2 \alpha$ promotes angiogenic, glycolytic, erythropoietic, and anti-apoptotic pathways in the treatment of several ischemic disorders [100]. HIFs induce a wide range of adaptive responses, the majority of which focus on upregulation of transcriptional cascades that are important for tissue protection and adaptation [101]. This includes the upregulation of glycolytic genes such as phosphoglycerate kinase (PGK) and lactate dehydrogenase A (LDHA), both of which help the tissues to adapt to low oxygen levels and anerobic ATP generation. Further, HIFs stimulate erythrocyte proliferation via erythropoietin (EPO) and angiogenesis via vascular endothelial growth factor (VEGF), which are important to improve oxygen supply to the hypoxic region. Of the two isoforms of HIFs, HIF-1 regulates the majority of these processes and is expressed systemically [100].

The role of HIF- $1 \alpha$ stabilization in the management of ischemic diseases is vital. Adenoviral transfer of HIF- $1 \alpha$ to a model of critical limb ischemia secondary to diabetes decreased tissue necrosis, activated eNOS, and enhanced the recovery of limb perfusion and function [102]. The HIF-1 pathway is a major regulator of hypoxia-induced angiogenesis, in which case it acts in synergy with VEGF, the master regulator of angiogenesis [103]. VEGF is a major transcriptional target for HIF-1 [104], where VEGF was found essential for the HIF-1 mediated neovascularization [105]. In ischemic stroke, VEGF was found to possess potent anti-inflammatory effects, promote angiogenesis, and protect ischemic neurons from injury [106]. VEGF mediates proliferation, migration, and survival of endothelial cells through upregulation of mitogen-activated protein kinase (MAPK) pathways [107]. A clinical trial that involved the delivery of VEGF on a plasmid resulted in effective collateral formation of blood vessels in ischemic limbs [108].

A

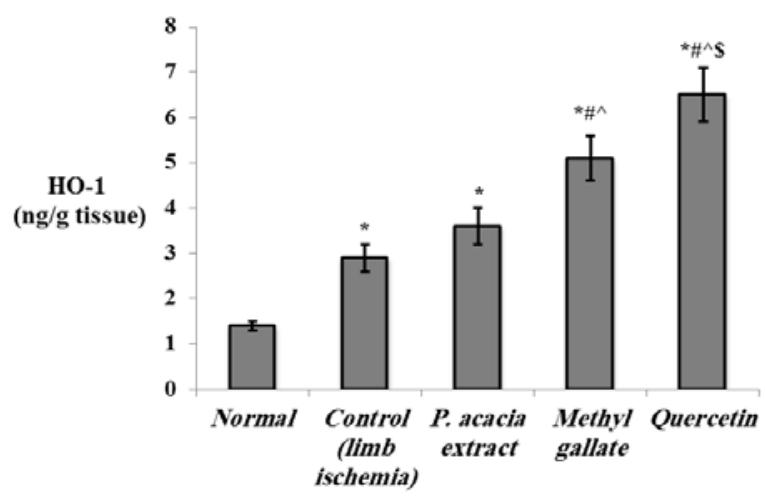

B

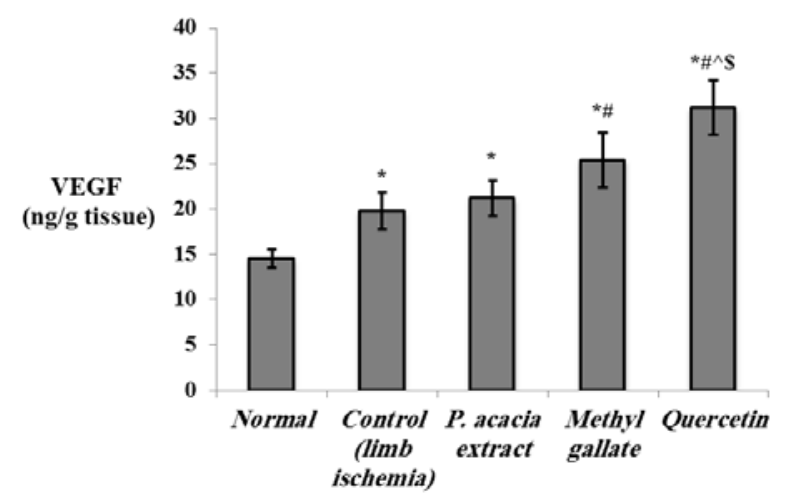

Figure 7. The effect of the P. acacia extract and its isolated compounds (methyl gallate and quercetin) on the levels of (A) HO-1 and (B) VEGF in the hind limb tissue of the experimental rats $(n=8)$. HO-1 = heme oxygenase-1; VEGF = vascular endothelial growth factor. Data are expressed as the mean \pm SD and were analyzed using one-way ANOVA followed by Bonferroni's post hoc test. * Significantly different compared to the normal group, ${ }^{\#}$ significantly different compared to the hind limb ischemia control group, ^ significantly different compared to the group treated with the P. acacia extract, ${ }^{\$}$ significantly different compared to the group treated with methyl gallate. Values were considered significantly different at $p<0.05$. 
A

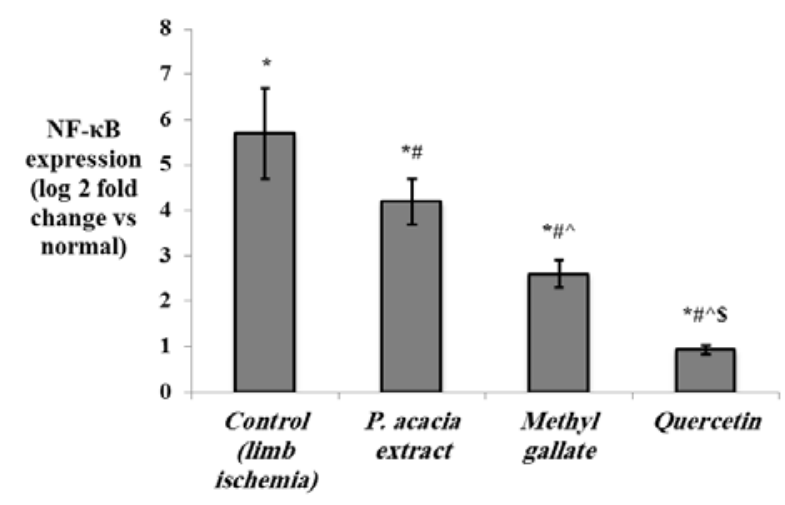

C

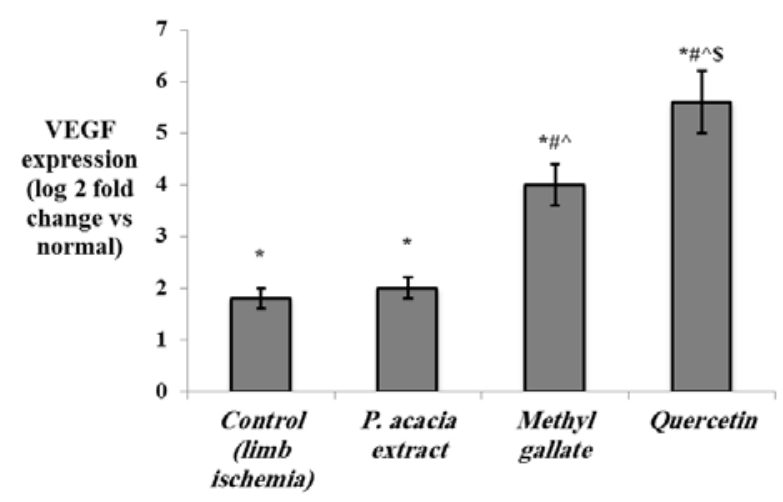

B

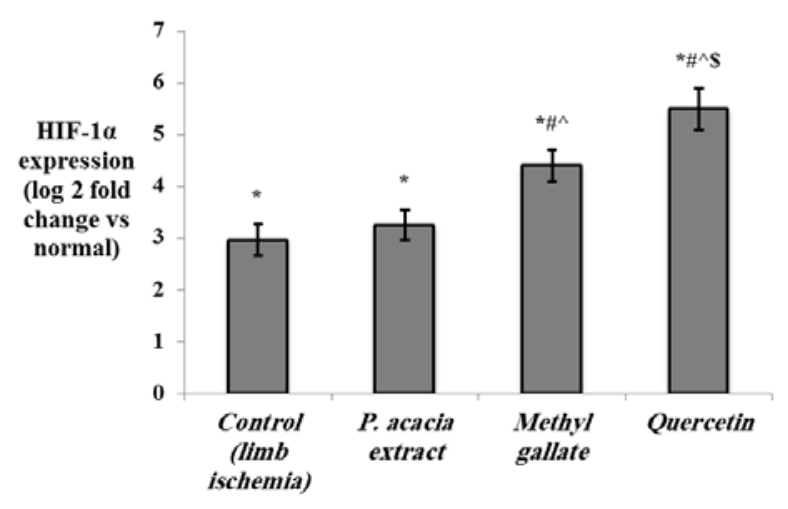

D

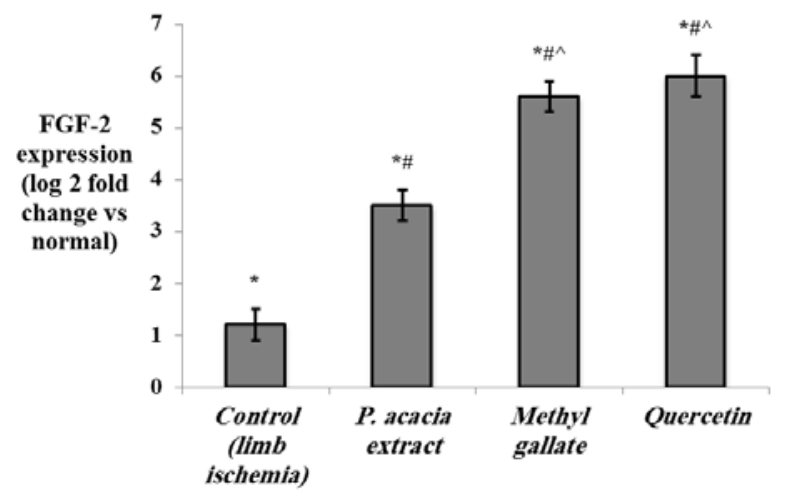

Figure 8. The effect of the P. acacia extract and its isolated compounds (methyl gallate and quercetin) on the expression levels of (A) NF- $\kappa$ B, (B) HIF-1 $\alpha$ (C) VEGF, and (D) FGF-2 in the hind limb tissue of the experimental rats. $(n=8)$. NF- $\kappa \mathrm{B}=$ nuclear factor kappa B; HIF-1 $\alpha$ = hypoxia inducible factor-1 alpha; VEGF = vascular endothelial growth factor; FGF-2 = fibroblast growth factor-2. Data are expressed as mean \pm SD of the $\log 2$ fold change relative to the normal group $(\log 2(1)=$ zero, i.e., base line). Data were analyzed using one-way ANOVA followed by Bonferroni's post hoc test. * Significantly different compared to the normal group, " significantly different compared to the hind limb ischemia control group, ^ significantly different compared to the group treated with the P. acacia extract, ${ }^{\$}$ significantly different compared to the group treated with methyl gallate. Values were considered significantly different at $p<0.05$.

Another promising pro-angiogenic factor is FGF-2 that contributes to angiogenesis in synergy with VEGF by inducing proliferation and migration of endothelial cells [107]. FGF2 is upregulated in response to hypoxia where it interacts with HIF-1 $\alpha$ [109]. Importantly, NO stabilizes HIF- $1 \alpha$ and stimulates secretion of VEGF and FGF- 2 from endothelial cells and macrophages, leading to induction of angiogenesis [110]. In experimental critical limb ischemia, therapeutic angiogenesis was mediated by combined actions of VEGF and FGF-2 [111]. FGF-2 was reported to inhibit endoplasmic reticulum stress and attenuate renal ischemia reperfusion injury [112].

In line with the current findings, quercetin was reported to promote angiogenesis in ischemic tissue but not in tumor tissues [113]. This might be explained by its ability to upregulate HO-1 [114]. Quercetin has been listed as a natural inducer of HO-1 via the MAPK/the nuclear factor erythroid 2-related factor 2 (Nrf2) pathways [115,116]. Nrf2 negatively controls the NF- $\mathrm{kB}$ signaling pathway. Nrf2 induces increases in the cellular expression of HO-1, leading to inhibition of the oxidative stress-mediated NF- $\mathrm{kB}$ activation. Additionally, Nrf2 negatively regulates the inhibitor kappa B-alpha (IкB- $\alpha$ ) proteasomal 
degradation and nuclear translocation of NF- $\mathrm{KB}$ [117]. This matches with our results, where the expression of NF- $\mathrm{kB}$ was significantly downregulated in the treated groups.

NF- $k B$ was found to be a transcriptional activator of HIF- $1 \alpha$, linking ischemia to innate immunity and inflammation [104]. Inhibition of TLR4 and NF- $\mathrm{kB}$ pathways was involved in amelioration of acute kidney injury induced by limb ischemia/reperfusion [118]. Similar results were reported in lung injury induced by limb ischemia where suppression of TLR-4 and NF- $\mathrm{kB}$ had a protective effect [119]. Quercetin is known to possess anti-inflammatory properties by inhibiting the transcriptional activity of NF-KB [120].

The results of the present study also demonstrated downregulation of miR-146a in the hind limb ischemia control rats vs. the normal group $(p<0.001)$, with significant upregulation in all treated groups, particularly quercetin (Figure 9).

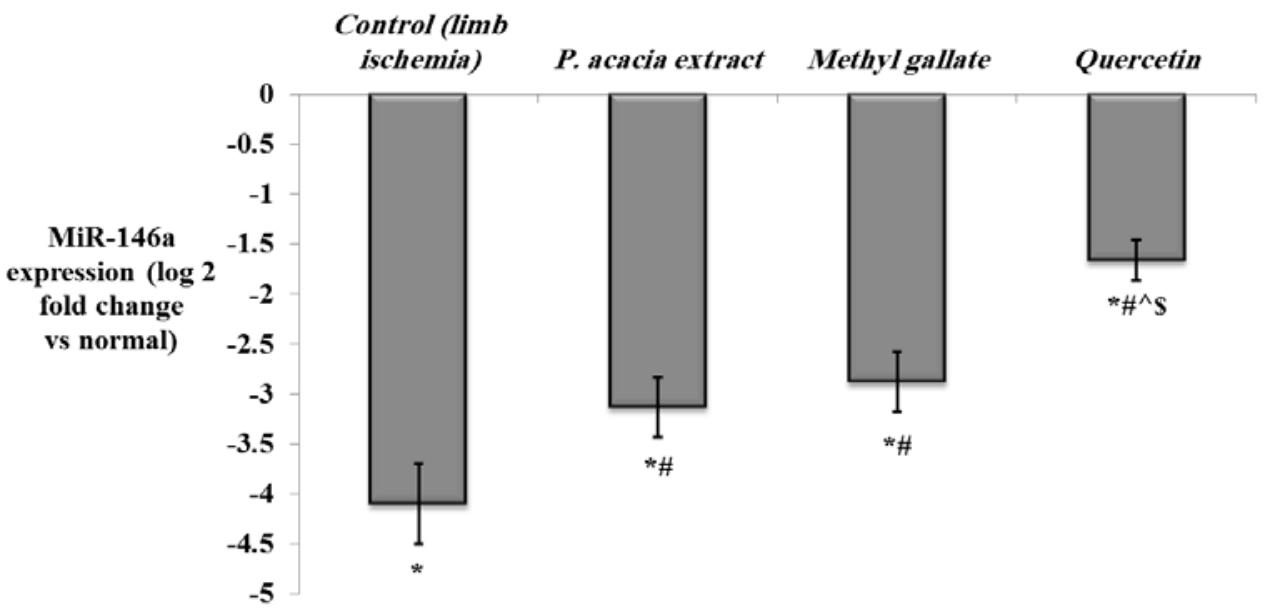

Figure 9. The effect of the P. acacia extract and its isolated compounds (methyl gallate and quercetin) on the expression levels of miR-146a in the hind limb tissue of the experimental rats. $(n=8)$. Data are expressed as mean \pm SD of the log 2 fold change relative to the normal group $(\log 2(1)=$ zero, i.e., base line). Data were analyzed using one-way ANOVA followed by Bonferroni's post hoc test. ${ }^{*}$ Significantly different compared to the normal group, ${ }^{*}$ significantly different compared to the hind limb ischemia control group, $\wedge$ significantly different compared to the group treated with the $P$. acacia extract, $\$$ significantly different compared to the group treated with methyl gallate. Values were considered significantly different at $p<0.05$.

The expression of miR-146a was reported to be downregulated in acute ischemic stroke [121]. Similarly, the expression of miR-146a was decreased in mice Kupffer cells following hepatic ischemia/reperfusion [122]. The upregulation of miR-146a was suggested to have a protective role against myocardial ischemia reperfusion injury [123]. Moreover, miR-146a was proved to ameliorate liver ischemia/reperfusion injury by suppressing interleukin-1 receptor-associated kinase 1 (IRAK1) and tumor necrosis factor receptorassociated factor 6 (TRAF6), leading to the inhibition of NF-KB [122]. Additionally, miR146a expression was downregulated in small intestine ischemia. However, upregulation of miR-146a was found to have a protective role against intestinal ischemia/reperfusion injury through inhibition of the TLR4/TRAF6/NF-KB pathway [124]. Upregulation of miR146a during angiogenesis was frequently reported. Overexpression of miR-146a in human umbilical vein endothelial cells resulted in up-regulation of angiogenesis-associated genes including FGF2 [125]. miR-146a was also reported to enhance angiogenesis of endothelial cells in hepatocellular carcinoma by promoting the expression of platelet-derived growth factor receptor $\alpha$ (PDGFRA) [126]. Interestingly, the levels of miR-146a were negatively correlated with inflammatory and oxidative stress markers, but positively correlated with the levels of Nrf2, HO-1, and SOD in the brain of chronic type 2 diabetic rats [127]. In agreement with our findings, quercetin was recently reported to upregulate miR-146a in fibroblast-like synoviocytes of rheumatoid arthritis [128]. 
In conclusion, the current study suggests a beneficial role of methyl gallate and quercetin isolated from P. acacia in the alleviation of lower limb ischemia induced in diabetic rats, through their antioxidant effects, along with their ability to induce angiogenesis via induction of HO-1, HIF-1 $\alpha$, VEGF, FGF-2, and miR-146a. This study adds novel insights into the biological activities of the studied compounds, especially methyl gallate that, despite being known as a potent antioxidant, is not yet extensively studied with respect to its biochemical and molecular effects.

Supplementary Materials: The following are available online at https://www.mdpi.com/article/ 10.3390/antiox10111701/s1, Figures S1 and S2: LC-ESI-HR-MS of the crude extract (positive and negative modes), Figures S3 and S4: ${ }^{1} \mathrm{H}$ NMR, ${ }^{13} \mathrm{C}$ NMR spectra of compound $\mathbf{1}$.

Author Contributions: Conceptualization, D.M.A.-E., J.M.B., M.S.A.-K.; methodology, A.R.A.-H., E.T.M., R.M.H., M.S.G.; data curation, E.T.M., J.M.B., M.S.G.; original draft preparation, A.R.A.-H., E.T.M., R.M.H., J.M.B., M.S.G.; writing, review, and editing, all authors. All authors have read and agreed to the published version of the manuscript.

Funding: This research received no external funding.

Institutional Review Board Statement: The study protocol has been approved by the research ethics committee at Faculty of Pharmacy, Suez Canal University, Ismailia, Egypt (Ethics code: 202106RA1) in agreement with the Guidelines of Canadian Council on Animal Care.

Informed Consent Statement: Not applicable.

Data Availability Statement: Data is available within the article and Supplementary Materials.

Acknowledgments: This publication was supported by the Deanship of Scientific Research at Prince Sattam Bin Abdulaziz University, Al-Kharj, Saudi Arabia, as well as Suez Canal University, Ismailia, Egypt.

Conflicts of Interest: The authors declare no conflict of interest.

\section{References}

1. Martin, A.; Komada, M.R.; Sane, D.C. Abnormal angiogenesis in diabetes mellitus. Med. Res. Rev. 2003, 23, 117-145. [CrossRef]

2. Olin, J.W.; Sealove, B.A. Peripheral artery disease: Current insight into the disease and its diagnosis and management. Mayo Clin. Proc. 2010, 85, 678-692. [CrossRef]

3. Norgren, L.; Hiatt, W.R.; Dormandy, J.A.; Nehler, M.R.; Harris, K.A.; Fowkes, F.G.; TASC II Working Group. Inter-Society Consensus for the Management of Peripheral Arterial Disease (TASC II). J. Vasc. Surg. 2007, 45, S5-S67. [CrossRef] [PubMed]

4. Reinecke, H.; Unrath, M.; Freisinger, E.; Bunzemeier, H.; Meyborg, M.; Lüders, F.; Gebauer, K.; Roeder, N.; Berger, K.; Malyar, N.M. Peripheral arterial disease and critical limb ischaemia: Still poor outcomes and lack of guideline adherence. Eur. Heart J. 2015, 36, 932-938. [CrossRef] [PubMed]

5. Heil, M.; Eitenmüller, I.; Schmitz-Rixen, T.; Schaper, W. Arteriogenesis versus angiogenesis: Similarities and differences. J. Cell. Mol. Med. 2006, 10, 45-55. [CrossRef]

6. Annex, B.H. Therapeutic angiogenesis for critical limb ischaemia. Nat. Rev. Cardiol. 2013, 10, 387-396. [CrossRef]

7. Al-Khaldi, A.; Al-Sabti, H.; Galipeau, J.; Lachapelle, K. Therapeutic angiogenesis using autologous bone marrow stromal cells: Improved blood flow in a chronic limb ischemia model. Ann. Thorac. Surg. 2003, 75, 204-209. [CrossRef]

8. Ozawa, C.R.; Banfi, A.; Glazer, N.L.; Thurston, G.; Springer, M.L.; Kraft, P.E.; McDonald, D.M.; Blau, H.M. Microenvironmental VEGF concentration, not total dose, determines a threshold between normal and aberrant angiogenesis. J. Clin. Investig. 2004, 113, 516-527. [CrossRef]

9. Wang, C.P.; Shi, Y.W.; Tang, M.; Zhang, X.C.; Gu, Y.; Liang, X.M.; Wang, Z.W.; Ding, F. Isoquercetin ameliorates cerebral impairment in focal ischemia through anti-oxidative, anti-inflammatory, and anti-apoptotic effects in primary culture of rat hippocampal neurons and hippocampal CA1 region of rats. Mol. Neurobiol. 2017, 54, 2126-2142. [CrossRef]

10. Dulak, J.; Deshane, J.; Jozkowicz, A.; Agarwal, A. Heme oxygenase-1 and carbon monoxide in vascular pathobiology: Focus on angiogenesis. Circulation 2008, 117, 231-241. [CrossRef] [PubMed]

11. Yu, J.; deMuinck, E.D.; Zhuang, Z.; Drinane, M.; Kauser, K.; Rubanyi, G.M.; Qian, H.S.; Murata, T.; Escalante, B.; Sessa, W.C. Endothelial nitric oxide synthase is critical for ischemic remodeling, mural cell recruitment, and blood flow reserve. Proc. Natl. Acad. Sci. USA 2005, 102, 10999-11004. [CrossRef]

12. Foresti, R.; Motterlini, R. The heme oxygenase pathway and its interaction with nitric oxide in the control of cellular homeostasis. Free Radic. Res. 1999, 31, 459-475. [CrossRef] [PubMed]

13. Zorofchian Moghadamtousi, S.; Hajrezaei, M.; Abdul Kadir, H.; Zandi, K. Loranthus micranthus Linn.: Biological activities and phytochemistry. Evid. Based Complement. Altern. Med. 2013, 2013, 273712. [CrossRef] [PubMed] 
14. Deeni, Y.Y.; Sadiq, N.M. Antimicrobial properties and phytochemical constituents of the leaves of African mistletoe (Tapinanthus dodoneifolius (DC) Danser) (Loranthaceae): An ethnomedicinal plant of Hausaland, Northern Nigeria. J. Ethnopharmacol. 2002, 83, 235-240. [CrossRef]

15. Costa, R.M.; Vaz, A.F.; Oliva, M.L.; Coelho, L.C.; Correia, M.T.; Carneiro-daCunha, M.G. A new mistletoe Phthirusa pyrifolia leaf lectin with antimicrobial properties. Process. Biochem. 2010, 45, 526-533. [CrossRef]

16. Obatomi, D.K.; Bikomo, E.O.; Temple, V.J. Anti-diabetic properties of the African mistletoe in streptozotocin-induced diabetic rats. J. Ethnopharmacol. 1994, 43, 13-17. [CrossRef]

17. Osadebe, P.O.; Okide, G.B.; Akabogu, I.C. Study on anti-diabetic activities of crude methanolic extracts of Loranthus micranthus (Linn.) sourced from five different host trees. J. Ethnopharmacol. 2004, 95, 133-138. [CrossRef]

18. Moreno-Salazara, S.F.; Robles-Zepedab, R.E.; Johnsona, D.E. Plant folk medicines for gastrointestinal disorders among the main tribes of Sonora, Mexico. Fitoterapia 2008, 79, 132-141. [CrossRef]

19. Elegami, A.A.; Elnima, E.I.; Muddathir, A.K.; Omer, M.E. Antimicrobial activity of Plicosepalus acaciae. Fitoterapia 2001, 72, 431-434. [CrossRef]

20. Aldawsari, H.M.; Hanafy, A.; Labib, G.S.; Badr, G.M. Antihyperglycemic Activities of Extracts of the Mistletoes Plicosepalus acaciae and P. curviflorus in comparison to their solid lipid nanoparticle suspension formulations. Z. Naturforsch. C J. Biosci. 2014, 69, 391-398. [CrossRef]

21. Badr, J.M.; Shaala, L.A.; Youssef, D.T.A. Loranthin: A new polyhydroxylated flavanocoumarin from Plicosepalus acacia with significant free radical scavenging and antimicrobial activity. Phytochem. Lett. 2013, 6, 113-117. [CrossRef]

22. Bamane, F.H.; Badr, J.M.; Amin, O.A. Antioxidant activities and flavonoid contents of selected plants belonging to family Loranthaceae. Afr. J. Biotechnol. 2012, 11, 14380-14385. [CrossRef]

23. Hegazy, M.M.; Metwaly, A.M.; Mostafa, A.E.; Radwan, M.M.; Mehany, A.B.M.; Ahmed, E.; Enany, S.; Magdeldin, S.; Afifi, W.M.; ElSohly, M.A. Biological and chemical evaluation of some african plants belonging to Kalanchoe species: Antitrypanosomal, cytotoxic, antitopoisomerase activities and chemical profiling using ultra-performance liquid chromatography/ quadrupole-timeof-flight mass spectrometer. Pharmacogn. Mag. 2021, 17, 73. [CrossRef]

24. Mohammed, H.A.; Khan, R.A.; Abdel-Hafez, A.A.; Abdel-Aziz, M.; Ahmed, E.; Enany, S.; Mahgoub, S.; Al-Rugaie, O.; Alsharidah, M.; Aly, M.S.A.; et al. Phytochemical profiling, in vitro and in silico anti-microbial and anti-cancer activity evaluations and Staph GyraseB and h-TOP-II $\beta$ receptor-docking studies of major constituents of Zygophyllum coccineum L. Aqueous-ethanolic extract and its subsequent fractions: An approach to validate traditional phytomedicinal knowledge. Molecules 2021, 26, 577. [CrossRef] [PubMed]

25. Al-Nimry, S.S.; Khanfar, M.S. Validation of an RP-HPLC Method for the Determination of Asenapine Maleate in Dissolution Media and Application to Study In Vitro Release from Co-Crystals. Sci. Pharm. 2021, 89, 14. [CrossRef]

26. Taniyama, Y.; Morishita, R.; Aoki, M.; Nakagami, H.; Yamamoto, K.; Yamazaki, K.; Matsumoto, K.; Nakamura, T.; Kaneda, Y.; Ogihara, T. Therapeutic angiogenesis induced by human hepatocyte growth factor gene in rat and rabbit hindlimb ischemia models: Preclinical study for treatment of peripheral arterial disease. Gene Ther. 2001, 8, 181-189. [CrossRef] [PubMed]

27. Katayama, A.; Yamamoto, Y.; Tanaka, K.; Matsubara, K.; Sugitani, M.; Fujihara, S.; Harada, S.; Kaetsu, Y.; Yoshida, A.; Hisatome, I. Fenofibrate enhances neovascularization in a murine ischemic hindlimb model. J. Cardiovasc. Pharmacol. 2009, 54, 399-404. [CrossRef]

28. Köksoy, C.; Oziş, E.; Cakmak, A.; Yazgan, U.; Okcu-Heper, A.; Köksoy, A.; Demirpençe, E.; Deniz Dinçer, U. Simvastatin pretreatment reduces the severity of limb ischemia in an experimental diabetes model. J. Vasc. Surg. 2007, 45, 590-596. [CrossRef]

29. Jokinen, M.P.; Lieuallen, W.G.; Boyle, M.C.; Johnson, C.L.; Malarkey, D.E.; Nyska, A. Morphologic aspects of rodent cardiotoxicity in a retrospective evaluation of National Toxicology Program studies. Toxicol. Pathol. 2011, 39, 850-860. [CrossRef]

30. Lang, R.; Yagar, E.F.; Eggers, R.; Hofmann, T. Quantitative investigation of trigonelline, nicotinic acid, and nicotinamide in foods, urine, and plasma by means of LC-MS/MS and stable isotope dilution analysis. J. Agric. Food Chem. 2008, 56, 11114-11121. [CrossRef]

31. Mendes, V.M.; Coelho, M.; Tomé, A.R.; Cunha, R.A.; Manadas, B. Validation of an LC-MS/MS method for the quantification of caffeine and theobromine using non-matched matrix calibration curve. Molecules 2019, 24, 2863. [CrossRef]

32. Cai, R.J.; Yin, X.L.; Liu, J.; Qin, D.X.; Zhao, G.Z. Characterization and identification of in vitro metabolites of (-)-epicatechin using ultra-high performance liquid chromatography-mass spectrometry. Trop. J. Pharm. Res. 2018, 16, 2985. [CrossRef]

33. Wang, X.; Yan, K.; Ma, X.; Li, W.; Chu, Y.; Guo, J.; Li, S.; Zhou, Y.; Liu, C. Simultaneous determination and pharmacokinetic study of protocatechuic aldehyde and its major active metabolite protocatechuic acid in rat plasma by liquid chromatography-tandem mass spectrometry. J. Chromatogr. Sci. 2016, 54, 697-705. [CrossRef]

34. Grieman, M.M.; Greaves, J.; Saltzman, E.S. A method for analysis of vanillic acid in polar ice cores. Clim. Past 2015, 11, 227-232. [CrossRef]

35. Lin, Y.; Xu, W.; Huang, M.; Xu, W.; Li, H.; Ye, M.; Zhang, Z.; Chu, K. Qualitative and quantitative analysis of phenolic acids, flavonoids and iridoid glycosides in Yinhua Kanggan tablet by uplc-qqq-ms/ms. Molecules 2015, 20, 12209-12228. [CrossRef]

36. Yang, C.-J.; Wang, Z.-B.; Mi, Y.-Y.; Gao, M.-J.; Lv, J.-N.; Meng, Y.-H.; Yang, B.-Y.; Kuang, H.-X. UHPLC-MS/MS Determination, pharmacokinetic, and bioavailability study of taxifolin in rat plasma after oral administration of its nanodispersion. Molecules 2016, 21, 494. [CrossRef] 
37. Tine, Y.; Yang, Y.; Renucci, F.; Costa, J.; Wélé, A.; Paolini, J. LC-MS/MS Analysis of flavonoid compounds from Zanthoxylum zanthoxyloides extracts and their antioxidant activities. Nat. Prod. Commun. 2017, 12, 1865-1868. [CrossRef]

38. Lee, J.-T.; Pao, L.-H.; Hsieh, C.-D.; Huang, P.-W.; Hu, O.Y.-P. Development and validation of an LC-MS/MS method for simultaneous quantification of hesperidin and hesperetin in rat plasma for pharmacokinetic studies. Anal. Methods 2017, 9, 3329-3337. [CrossRef]

39. Šibul, F.; Orčić, D.; Berežni, S.; Anačkov, G.; Mimica-Dukić, N. HPLC-MS/MS profiling of wild-growing scentless chamomile. Acta Chromatogr. 2019, 32, 1-9. [CrossRef]

40. Tong, L.; Zhou, D.; Gao, J.; Zhu, Y.; Sun, H.; Bi, K. Simultaneous determination of naringin, hesperidin, neohesperidin, naringenin and hesperetin of Fractus aurantii extract in rat plasma by liquid chromatography tandem mass spectrometry. J. Pharm. Biomed. Anal. 2012, 58, 58-64. [CrossRef] [PubMed]

41. Campanero, M.A.; Escolar, M.; Perez, G.; Garcia-Quetglas, E.; Sadaba, B.; Azanza, J.R. Simultaneous determination of diosmin and diosmetin in human plasma by ion trap liquid chromatography-atmospheric pressure chemical ionization tandem mass spectrometry: Application to a clinical pharmacokinetic study. J. Pharm. Biomed. Anal. 2010, 51, 875-881. [CrossRef]

42. Bruce, S.J.; Guy, P.A.; Rezzi, S.; Ross, A.B. Quantitative measurement of betaine and free choline in plasma, cereals and cereal products by isotope dilution LC-MS/MS. J. Agric. Food Chem. 2010, 58, 2055-2061. [CrossRef] [PubMed]

43. Ellingson, D.J.; Shippar, J.J.; Gilmore, J.M. Determination of free and total choline and carnitine in infant formula and adult/pediatric nutritional formula by liquid chromatography/tandem mass spectrometry (LC/MS/MS): Single-Laboratory Validation, First Action 2015.10. J. AOAC Int. 2016, 99, 204-209. [CrossRef] [PubMed]

44. Chernonosov, A.A.; Karpova, E.A.; Lyakh, E.M. Identification of phenolic compounds in Myricaria bracteata leaves by highperformance liquid chromatography with a diode array detector and liquid chromatography with tandem mass spectrometry. Rev. Bras. Farmacogn. 2017, 27, 576-579. [CrossRef]

45. Noman, O.M.; Mothana, R.A.; Al-Rehaily, A.J.; Al Qahtani, A.S.; Nasr, F.A.; Khaled, J.M.; Alajmi, M.F.; Al-Said, M.S. Phytochemical analysis and anti-diabetic, anti-inflammatory and antioxidant activities of Loranthus acaciae Zucc. Grown in Saudi Arabia. Saudi Pharm. J. 2019, 27, 724-730. [CrossRef]

46. Abdelhameed, R.F.A.; Habib, E.S.; Goda, M.S.; Fahim, J.R.; Hassanean, H.A.; Eltamany, E.E.; Ibrahim, A.K.; AboulMagd, A.M.; Fayez, S.; El-kader, A.M.A.; et al. Thalassosterol, a new cytotoxic aromatase inhibitor ergosterol derivative from the Red Sea seagrass Thalassodendron ciliatum. Mar. Drugs 2020, 18, 354. [CrossRef]

47. Prakash, M.; Basavaraj, B.V.; Chidambara-Murthy, K.N. Biological functions of epicatechin: Plant cell to human cell health. J. Funct. Foods 2019, 52, 14-24. [CrossRef]

48. Vieira, A.J.S.C.; Gaspar, E.M.; Santos, P.M.P. Mechanisms of potential antioxidant activity of caffeine. Radiat. Phys. Chem. 2020, 174, 108968. [CrossRef]

49. Shubina, V.S.; Kozina, V.I.; Shatalin, Y.V. Comparison of antioxidant properties of a conjugate of taxifolin with glyoxylic acid and selected flavonoids. Antioxidants 2021, 10, 1262. [CrossRef]

50. Tan, Y.; Tam, C.C.; Rolston, M.; Alves, P.; Chen, L.; Meng, S.; Hong, H.; Chang, S.K.C.; Yokoyama, W. Quercetin ameliorates insulin resistance and restores gut microbiome in mice on high-fat diets. Antioxidants 2021, 10, 1251. [CrossRef]

51. Kopustinskiene, D.M.; Jakstas, V.; Savickas, A.; Bernatoniene, J. Flavonoids as Anticancer Agents. Nutrients $2020,12,457$. [CrossRef] [PubMed]

52. Zhou, J.; Chan, L.; Zhou, S. Trigonelline: A plant alkaloid with therapeutic potential for diabetes and central nervous system disease. Curr. Med. Chem. 2012, 19, 3523-3531. [CrossRef] [PubMed]

53. Kakkar, S.; Bais, S. A Review on protocatechuic acid and its pharmacological potential. ISRN Pharmacol. 2014, $2014,952943$. [CrossRef]

54. Huang, H.; Song, L.; Zhang, H.; Zhang, H.; Zhang, J.; Zhao, W. Influence of L-carnitine supplementation on serum lipid profile in hemodialysis patients: A systematic review and meta-analysis. Kidney Blood Press. Res. 2013, 38, 31-41. [CrossRef] [PubMed]

55. Yu, J.; Dardik, A. A Murine Model of Hind Limb Ischemia to Study Angiogenesis and Arteriogenesis. Methods Mol. Biol. 2018, 1717, 135-143. [CrossRef]

56. Taniyama, Y.; Morishita, R.; Hiraoka, K.; Aoki, M.; Nakagami, H.; Yamasaki, K.; Matsumoto, K.; Nakamura, T.; Kaneda, Y.; Ogihara, T. Therapeutic angiogenesis induced by human hepatocyte growth factor gene in rat diabetic hind limb ischemia model: Molecular mechanisms of delayed angiogenesis in diabetes. Circulation 2001, 104, 2344-2350. [CrossRef]

57. Ferraro, B.; Cruz, Y.L.; Baldwin, M.; Coppola, D.; Heller, R. Increased perfusion and angiogenesis in a hindlimb ischemia model with plasmid FGF-2 delivered by noninvasive electroporation. Gene Ther. 2010, 17, 763-769. [CrossRef]

58. So, K.; Tei, Y.; Zhao, M.; Miyake, T.; Hiyama, H.; Shirakawa, H.; Imai, S.; Mori, Y.; Nakagawa, T.; Matsubara, K.; et al. Hypoxiainduced sensitisation of TRPA1 in painful dysesthesia evoked by transient hindlimb ischemia/reperfusion in mice. Sci. Rep. 2016, 6, 23261. [CrossRef]

59. Kuroda, Y.; Togashi, H.; Uchida, T.; Haga, K.; Yamashita, A.; Sadahiro, M. Oxidative stress evaluation of skeletal muscle in ischemia-reperfusion injury using enhanced magnetic resonance imaging. Sci. Rep. 2020, 10, 10863. [CrossRef] [PubMed]

60. Kim, Y.W.; Byzova, T.V. Oxidative stress in angiogenesis and vascular disease. Blood 2014, 123, 625-631. [CrossRef]

61. Sasaki, H.; Fukuda, S.; Otani, H.; Zhu, L.; Yamaura, G.; Engelman, R.M.; Das, D.K.; Maulik, N. Hypoxic preconditioning triggers myocardial angiogenesis: A novel approach to enhance contractile functional reserve in rat with myocardial infarction. J. Mol. Cell. Cardiol. 2002, 34, 335-348. [CrossRef] 
62. Li, J.; Wang, J.J.; Yu, Q.; Chen, K.; Mahadev, K.; Zhang, S.X. Inhibition of reactive oxygen species by Lovastatin downregulates vascular endothelial growth factor expression and ameliorates blood-retinal barrier breakdown in db/db mice: Role of NADPH oxidase 4. Diabetes 2010, 59, 1528-1538. [CrossRef]

63. Colavitti, R.; Pani, G.; Bedogni, B.; Anzevino, R.; Borrello, S.; Waltenberger, J.; Galeotti, T. Reactive oxygen species as downstream mediators of angiogenic signaling by vascular endothelial growth factor receptor-2/KDR. J. Biol. Chem. 2002, 277, 3101-3108. [CrossRef]

64. Birukova, A.A.; Lee, S.; Starosta, V.; Wu, T.; Ho, T.; Kim, J.; Berliner, J.A.; Birukov, K.G. A role for VEGFR2 activation in endothelial responses caused by barrier disruptive OxPAPC concentrations. PLoS ONE 2012, 7, e30957. [CrossRef] [PubMed]

65. Bochkov, V.N.; Philippova, M.; Oskolkova, O.; Kadl, A.; Furnkranz, A.; Karabeg, E.; Afonyushkin, T.; Gruber, F.; Breuss, J.; Minchenko, A.; et al. Oxidized phospholipids stimulate angiogenesis via autocrine mechanisms, implicating a novel role for lipid oxidation in the evolution of atherosclerotic lesions. Circ. Res. 2006, 99, 900-908. [CrossRef]

66. Hutter, R.; Speidl, W.S.; Valdiviezo, C.; Sauter, B.; Corti, R.; Fuster, V.; Badimon, J.J. Macrophages transmit potent proangiogenic effects of oxLDL in vitro and in vivo involving HIF- $1 \alpha$ activation: A novel aspect of angiogenesis in atherosclerosis. J. Cardiovasc. Transl. Res. 2013, 6, 558-569. [CrossRef]

67. Wu, Q.; Finley, S.D. Mathematical Model Predicts Effective Strategies to Inhibit VEGF-eNOS Signaling. J. Clin. Med. 2020, 9, 1255. [CrossRef]

68. Kim, Y.W.; West, X.Z.; Byzova, T.V. Inflammation and oxidative stress in angiogenesis and vascular disease. J. Mol. Med. 2013, 91, 323-328. [CrossRef]

69. Mutoh, A.; Ueda, S. Peroxidized unsaturated fatty acids stimulate Toll-like receptor 4 signaling in endothelial cells. Life Sci. 2013, 92, 984-992. [CrossRef]

70. Schreml, S.; Szeimies, R.M.; Prantl, L.; Karrer, S.; Landthaler, M.; Babilas, P. Oxygen in acute and chronic wound healing. Br. J. Dermatol. 2010, 163, 257-268. [CrossRef]

71. Spirig, R.; Djafarzadeh, S.; Regueira, T.; Shaw, S.G.; von Garnier, C.; Takala, J.; Jakob, S.M.; Rieben, R.; Lepper, P.M. Effects of TLR agonists on the hypoxia-regulated transcription factor HIF-1alpha and dendritic cell maturation under normoxic conditions. PLoS ONE 2010, 5, e0010983. [CrossRef] [PubMed]

72. Kao, M.C.; Chung, C.Y.; Chang, Y.Y.; Lin, C.K.; Sheu, J.R.; Huang, C.J. Salutary Effects of Cepharanthine against Skeletal Muscle and Kidney Injuries following Limb Ischemia/Reperfusion. Evid. Based Complement. Alternat. Med. 2015, 2015, 504061. [CrossRef]

73. Tong, J.; Zhang, Y.; Yu, P.; Liu, J.; Mei, X.; Meng, J. Protective Effect of Hydrogen Gas on Mice Hind Limb Ischemia-Reperfusion Injury. J. Surg. Res. 2021, 266, 148-159. [CrossRef] [PubMed]

74. Ryan, T.E.; Schmidt, C.A.; Green, T.D.; Spangenburg, E.E.; Neufer, P.D.; McClung, J.M. Targeted Expression of Catalase to Mitochondria Protects Against Ischemic Myopathy in High-Fat Diet-Fed Mice. Diabetes 2016, 65, 2553-2568. [CrossRef]

75. Zaghloul, N.; Patel, H.; Codipilly, C.; Marambaud, P.; Dewey, S.; Frattini, S.; Huerta, P.T.; Nasim, M.; Miller, E.J.; Ahmed, M. Overexpression of extracellular superoxide dismutase protects against brain injury induced by chronic hypoxia. PLoS ONE 2014, 9, e108168. [CrossRef]

76. Crispo, J.A.; Ansell, D.R.; Piche, M.; Eibl, J.K.; Khaper, N.; Ross, G.M.; Tai, T.C. Protective effects of polyphenolic compounds on oxidative stress-induced cytotoxicity in PC12 cells. Can. J. Physiol. Pharmacol. 2010, 88, 429-438. [CrossRef]

77. Asnaashari, M.; Farhoosh, R.; Sharif, A. Antioxidant activity of gallic acid and methyl gallate in triacylglycerols of Kilka fish oil and its oil-in-water emulsion. Food Chem. 2014, 159, 439-444. [CrossRef]

78. Wang, C.R.; Zhou, R.; Ng, T.B.; Wong, J.H.; Qiao, W.T.; Liu, F. First report on isolation of methyl gallate with antioxidant, anti-HIV-1 and HIV-1 enzyme inhibitory activities from a mushroom (Pholiota adiposa). Environ. Toxicol. Pharmacol. 2014, 37, 626-637. [CrossRef]

79. Farhoosh, R.; Nyström, L. Antioxidant potency of gallic acid, methyl gallate and their combinations in sunflower oil triacylglycerols at high temperature. Food Chem. 2018, 244, 29-35. [CrossRef]

80. Rahman, N.; Jeon, M.; Kim, Y.S. Methyl gallate, a potent antioxidant inhibits mouse and human adipocyte differentiation and oxidative stress in adipocytes through impairment of mitotic clonal expansion. Biofactors 2016, 42, 716-726. [CrossRef]

81. Ahmed, A.Z.; Satyam, S.M.; Shetty, P.; D'Souza, M.R. Methyl Gallate Attenuates Doxorubicin-Induced Cardiotoxicity in Rats by Suppressing Oxidative Stress. Scientifica 2021, 2021, 6694340. [CrossRef] [PubMed]

82. Xu, D.; Hu, M.J.; Wang, Y.Q.; Cui, Y.L. Antioxidant Activities of Quercetin and Its Complexes for Medicinal Application. Molecules 2019, 24, 1123. [CrossRef]

83. Kinaci, M.K.; Erkasap, N.; Kucuk, A.; Koken, T.; Tosun, M. Effects of quercetin on apoptosis, NF- $k B$ and NOS gene expression in renal ischemia/reperfusion injury. Exp. Ther. Med. 2012, 3, 249-254. [CrossRef] [PubMed]

84. Huang, R.; Zhong, T.; Wu, H. Quercetin protects against lipopolysaccharide-induced acute lung injury in rats through suppression of inflammation and oxidative stress. Arch. Med. Sci. 2015, 11, 427-432. [CrossRef] [PubMed]

85. Akkoyun, D.C.; Akyuz, A.; Dogan, M.; Erboga, M.; Aktas, C.; Caglar, V.; Uygur, R.; Topcu, B.; Yilmaz, A.; Gurel, A. Quercetin Inhibits Heart Injury in Lipopolysaccharide-induced Endotoxemic Model by Suppressing the Effects of Reactive Oxygen Species. Anal. Quant. Cytopathol. Histopathol. 2016, 38, 183-188.

86. Yan, J.; Tie, G.; Park, B.; Yan, Y.; Nowicki, P.T.; Messina, L.M. Recovery from hind limb ischemia is less effective in type 2 than in type 1 diabetic mice: Roles of endothelial nitric oxide synthase and endothelial progenitor cells. J. Vasc. Surg. 2009, 50, 1412-1422. [CrossRef] 
87. Sorrentino, S.; Iaconetti, C.; De Rosa, S.; Polimeni, A.; Sabatino, J.; Gareri, C.; Passafaro, F.; Mancuso, T.; Tammè, L.; Mignogna, C.; et al. Hindlimb Ischemia Impairs Endothelial Recovery and Increases Neointimal Proliferation in the Carotid Artery. Sci. Rep. 2018, 8, 761. [CrossRef]

88. Yang, C.; Hwang, H.H.; Jeong, S.; Seo, D.; Jeong, Y.; Lee, D.Y.; Lee, K. Inducing angiogenesis with the controlled release of nitric oxide from biodegradable and biocompatible copolymeric nanoparticles. Int. J. Nanomed. 2018, 13, 6517-6530. [CrossRef] [PubMed]

89. Zhang, K.; Chen, X.; Li, H.; Feng, G.; Nie, Y.; Wei, Y.; Li, N.; Han, Z.; Han, Z.C.; Kong, D.; et al. A nitric oxide-releasing hydrogel for enhancing the therapeutic effects of mesenchymal stem cell therapy for hindlimb ischemia. Acta Biomater. 2020, 113, 289-304. [CrossRef] [PubMed]

90. Zhang, B.; Liu, Q.H.; Zhou, C.J.; Hu, M.Z.; Qian, H.X. Protective effect of eNOS overexpression against ischemia/reperfusion injury in small-for-size liver transplantation. Exp. Ther. Med. 2016, 12, 3181-3188. [CrossRef]

91. Park, B.; Hoffman, A.; Yang, Y.; Yan, J.; Tie, G.; Bagshahi, H.; Nowicki, P.T.; Messina, L.M. Endothelial nitric oxide synthase affects both early and late collateral arterial adaptation and blood flow recovery after induction of hind limb ischemia in mice. J. Vasc. Surg. 2010, 51, 165-173. [CrossRef]

92. Shen, Y.; Croft, K.D.; Hodgson, J.M.; Kyle, R.; Lee, I.L.; Wang, Y.; Stocker, R.; Ward, N.C. Quercetin and its metabolites improve vessel function by inducing eNOS activity via phosphorylation of AMPK. Biochem. Pharmacol. 2012, 84, 1036-1044. [CrossRef]

93. Li, P.G.; Sun, L.; Han, X.; Ling, S.; Gan, W.T.; Xu, J.W. Quercetin induces rapid eNOS phosphorylation and vasodilation by an Akt-independent and PKA-dependent mechanism. Pharmacology 2012, 89, 220-228. [CrossRef]

94. Chau, L.Y. Heme oxygenase-1: Emerging target of cancer therapy. J. Biomed. Sci. 2015, 22, 22. [CrossRef] [PubMed]

95. Lee, J.W.; Ko, J.; Ju, C.; Eltzschig, H.K. Hypoxia signaling in human diseases and therapeutic targets. Exp. Mol. Med. 2019, 51, 1-13. [CrossRef] [PubMed]

96. Dunn, L.L.; Kong, S.M.Y.; Tumanov, S.; Chen, W.; Cantley, J.; Ayer, A.; Maghzal, G.J.; Midwinter, R.G.; Chan, K.H.; Ng, M.K.C.; et al. Hmox1 (Heme Oxygenase-1) Protects Against Ischemia-Mediated Injury via Stabilization of HIF-1 $\alpha$ (Hypoxia-Inducible Factor-1 $\alpha$ ). Arterioscler. Thromb. Vasc. Biol. 2021, 41, 317-330. [CrossRef] [PubMed]

97. Rossi, M.; Thierry, A.; Delbauve, S.; Preyat, N.; Soares, M.P.; Roumeguère, T.; Leo, O.; Flamand, V.; Le Moine, A.; Hougardy, J.M. Specific expression of heme oxygenase-1 by myeloid cells modulates renal ischemia-reperfusion injury. Sci. Rep. 2017, 7, 197. [CrossRef] [PubMed]

98. Issan, Y.; Kornowski, R.; Aravot, D.; Shainberg, A.; Laniado-Schwartzman, M.; Sodhi, K.; Abraham, N.G.; Hochhauser, E. Heme oxygenase-1 induction improves cardiac function following myocardial ischemia by reducing oxidative stress. PLoS ONE 2014, 9, e92246. [CrossRef] [PubMed]

99. Loboda, A.; Jazwa, A.; Grochot-Przeczek, A.; Rutkowski, A.J.; Cisowski, J.; Agarwal, A.; Jozkowicz, A.; Dulak, J. Heme Oxygenase1 and the Vascular Bed: From Molecular Mechanisms to Therapeutic Opportunities. Antioxid. Redox Signal. 2008, 20, 1767-1812. [CrossRef]

100. Selvaraju, V.; Parinandi, N.L.; Adluri, R.S.; Goldman, J.W.; Hussain, N.; Sanchez, J.A.; Maulik, N. Molecular mechanisms of action and therapeutic uses of pharmacological inhibitors of HIF-prolyl 4-hydroxylases for treatment of ischemic diseases. Antioxid. Redox Signal. 2014, 20, 2631-2665. [CrossRef]

101. Hu, C.J.; Wang, L.Y.; Chodosh, L.A.; Keith, B.; Simon, M.C. Differential roles of hypoxia-inducible factor $1 \alpha(\mathrm{HIF}-1 \alpha)$ and HIF-2 $\alpha$ in hypoxic gene regulation. Mol. Cell. Biol. 2003, 23, 9361-9374. [CrossRef] [PubMed]

102. Sarkar, K.; Fox-Talbot, K.; Steenbergen, C.; Bosch-Marcé, M.; Semenza, G.L. Adenoviral transfer of HIF-1 alpha enhances vascular responses to critical limb ischemia in diabetic mice. Proc. Natl. Acad. Sci. USA 2009, 106, 18769-18774. [CrossRef] [PubMed]

103. Zimna, A.; Kurpisz, M. Hypoxia-Inducible Factor-1 in Physiological and Pathophysiological Angiogenesis: Applications and Therapies. Biomed. Res. Int. 2015, 2015, 549412. [CrossRef] [PubMed]

104. Ramakrishnan, S.; Anand, V.; Roy, S. Vascular endothelial growth factor signaling in hypoxia and inflammation. J. Neuroimmune Pharmacol. 2014, 9, 142-160. [CrossRef] [PubMed]

105. Oladipupo, S.; Hu, S.; Kovalski, J.; Yao, J.; Santeford, A.; Sohn, R.E.; Shohet, R.; Maslov, K.; Wang, L.V.; Arbeit, J.M. VEGF is essential for hypoxia-inducible factor-mediated neovascularization but dispensable for endothelial sprouting. Proc. Natl. Acad. Sci. USA 2011, 108, 13264-13269. [CrossRef]

106. Ma, Y.; Zechariah, A.; Qu, Y.; Hermann, D.M. Effects of vascular endothelial growth factor in ischemic stroke. J. Neurosci. Res. 2012, 90, 1873-1882. [CrossRef]

107. Samura, M.; Hosoyama, T.; Takeuchi, Y.; Ueno, K.; Morikage, N.; Hamano, K. Therapeutic strategies for cell-based neovascularization in critical limb ischemia. J. Transl. Med. 2017, 15, 49. [CrossRef]

108. Isner, J.M.; Pieczek, A.; Schainfeld, R.; Blair, R.; Haley, L.; Asahara, T.; Rosenfield, K.; Razvi, S.; Walsh, K.; Symes, J.F. Clinical evidence of angiogenesis after arterial gene transfer of phVEGF165 in patient with ischaemic limb. Lancet 1996, 348, 370-374. [CrossRef]

109. Conte, C.; Riant, E.; Toutain, C.; Pujol, F.; Arnal, J.F.; Lenfant, F.; Prats, A.C. FGF2 translationally induced by hypoxia is involved in negative and positive feedback loops with HIF-1alpha. PLoS ONE 2008, 3, e3078. [CrossRef]

110. Yamamoto, N.; Oyaizu, T.; Enomoto, M.; Horie, M.; Yuasa, M.; Okawa, A.; Yagishita, K. VEGF and bFGF induction by nitric oxide is associated with hyperbaric oxygen-induced angiogenesis and muscle regeneration. Sci. Rep. 2020, 10, 2744. [CrossRef] [PubMed] 
111. Masaki, I.; Yonemitsu, Y.; Yamashita, A.; Sata, S.; Tanii, M.; Komori, K.; Nakagawa, K.; Hou, X.; Nagai, Y.; Hasegawa, M.; et al. Angiogenic gene therapy for experimental critical limb ischemia: Acceleration of limb loss by overexpression of vascular endothelial growth factor 165 but not of fibroblast growth factor-2. Circ. Res. 2002, 90, 966-973. [CrossRef] [PubMed]

112. Tan, X.; Tao, Q.; Li, G.; Xiang, L.; Zheng, X.; Zhang, T.; Wu, C.; Li, D. Fibroblast Growth Factor 2 Attenuates Renal IschemiaReperfusion Injury via Inhibition of Endoplasmic Reticulum Stress. Front. Cell Dev. Biol. 2020, 8, 147. [CrossRef]

113. Sumi, M.; Tateishi, N.; Shibata, H.; Ohki, T.; Sata, M. Quercetin glucosides promote ischemia-induced angiogenesis, but do not promote tumor growth. Life Sci. 2013, 93, 814-819. [CrossRef]

114. Liu, S.; Tian, L.; Chai, G.; Wen, B.; Wang, B. Targeting heme oxygenase-1 by quercetin ameliorates alcohol-induced acute liver injury via inhibiting NLRP3 inflammasome activation. Food Funct. 2018, 9, 4184-4193. [CrossRef] [PubMed]

115. Sun, G.Y.; Chen, Z.; Jasmer, K.J.; Chuang, D.Y.; Gu, Z.; Hannink, M.; Simonyi, A. Quercetin Attenuates Inflammatory Responses in BV-2 Microglial Cells: Role of MAPKs on the Nrf2 Pathway and Induction of Heme Oxygenase-1. PLoS ONE 2015, 10, e0141509. [CrossRef]

116. Funes, S.C.; Rios, M.; Fernández-Fierro, A.; Covián, C.; Bueno, S.M.; Riedel, C.A.; Mackern-Oberti, J.P.; Kalergis, A.M. Naturally Derived Heme-Oxygenase 1 Inducers and Their Therapeutic Application to Immune-Mediated Diseases. Front. Immunol. 2020, 11, 1467. [CrossRef] [PubMed]

117. Saha, S.; Buttari, B.; Panieri, E.; Profumo, E.; Saso, L. An Overview of Nrf2 Signaling Pathway and Its Role in Inflammation. Molecules 2020, 25, 5474. [CrossRef]

118. Liu, Z.; Huang, W.; Chen, Y.; Du, Z.; Zhu, F.; Wang, T.; Jiang, B. Ischemic postconditioning ameliorates acute kidney injury induced by limb ischemia/reperfusion via transforming TLR4 and NF-kB signaling in rats. J. Orthop. Surg. Res. 2021, 16, 416. [CrossRef] [PubMed]

119. Xue, B.B.; Chen, B.H.; Tang, Y.N.; Weng, C.W.; Lin, L.N. Dexmedetomidine protects against lung injury induced by limb ischemia-reperfusion via the TLR4/MyD88/NF-kB pathway. Kaohsiung J. Med. Sci. 2019, 35, 672-678. [CrossRef]

120. Chekalina, N.; Burmak, Y.; Petrov, Y.; Borisova, Z.; Manusha, Y.; Kazakov, Y.; Kaidashev, I. Quercetin reduces the transcriptional activity of NF-kB in stable coronary artery disease. Indian Heart J. 2018, 70, 593-597. [CrossRef]

121. Li, S.H.; Chen, L.; Pang, X.M.; Su, S.Y.; Zhou, X.; Chen, C.Y.; Huang, L.G.; Li, J.P.; Liu, J.L. Decreased miR-146a expression in acute ischemic stroke directly targets the Fbxl10 mRNA and is involved in modulating apoptosis. Neurochem. Int. 2017, 107, 156-167. [CrossRef] [PubMed]

122. Jiang, W.; Kong, L.; Ni, Q.; Lu, Y.; Ding, W.; Liu, G.; Pu, L.; Tang, W.; Kong, L. miR-146a ameliorates liver ischemia/reperfusion injury by suppressing IRAK1 and TRAF6. PLoS ONE 2014, 9, e101530. [CrossRef] [PubMed]

123. Zhang, T.; Ma, Y.; Gao, L.; Mao, C.; Zeng, H.; Wang, X.; Sun, Y.; Gu, J.; Wang, Y.; Chen, K.; et al. MicroRNA-146a protects against myocardial ischaemia reperfusion injury by targeting Med1. Cell. Mol. Biol. Lett. 2019, 24, 62. [CrossRef]

124. He, X.; Zheng, Y.; Liu, S.; Shi, S.; Liu, Y.; He, Y.; Zhang, C.; Zhou, X. MiR-146a protects small intestine against ischemia/reperfusion injury by down-regulating TLR4/TRAF6/NF-кB pathway. J. Cell. Physiol. 2018, 233, 2476-2488. [CrossRef] [PubMed]

125. Zhu, H.Y.; Bai, W.D.; Liu, J.Q.; Zheng, Z.; Guan, H.; Zhou, Q.; Su, L.L.; Xie, S.T.; Wang, Y.C.; Li, J.; et al. Up-regulation of FGFBP1 signaling contributes to miR-146a-induced angiogenesis in human umbilical vein endothelial cells. Sci. Rep. 2016, 6, 25272. [CrossRef]

126. Zhu, K.; Pan, Q.; Zhang, X.; Kong, L.Q.; Fan, J.; Dai, Z.; Wang, L.; Yang, X.R.; Hu, J.; Wan, J.L.; et al. MiR-146a enhances angiogenic activity of endothelial cells in hepatocellular carcinoma by promoting PDGFRA expression. Carcinogenesis 2013, 34, 2071-2079. [CrossRef] [PubMed]

127. Xie, Y.; Chu, A.; Feng, Y.; Chen, L.; Shao, Y.; Luo, Q.; Deng, X.; Wu, M.; Shi, X.; Chen, Y. MicroRNA-146a: A Comprehensive Indicator of Inflammation and Oxidative Stress Status Induced in the Brain of Chronic T2DM Rats. Front. Pharmacol. 2018, 9, 478. [CrossRef] [PubMed]

128. Zhao, J.; Chen, B.; Peng, X.; Wang, C.; Wang, K.; Han, F.; Xu, J. Quercetin suppresses migration and invasion by targeting miR-146a/GATA6 axis in fibroblast-like synoviocytes of rheumatoid arthritis. Immunopharmacol. Immunotoxicol. 2020, 42, $221-227$. [CrossRef] 